\title{
Identification of Modulators of Hair Cell Regeneration in the Zebrafish Lateral Line
}

\author{
Parhum Namdaran, ${ }^{1,2}$ Katherine E. Reinhart, ${ }^{1,2}$ Kelly N. Owens, ${ }^{1,2}$ David W. Raible, ${ }^{1,3}$ and Edwin W Rubel ${ }^{1,2}$ \\ ${ }^{1}$ Virginia Merrill Bloedel Hearing Research Center, and Departments of ${ }^{2}$ Otolaryngology-Head and Neck Surgery and ${ }^{3}$ Biological Structure, University of \\ Washington, Seattle, Washington 98195
}

The external location of the zebrafish lateral line makes it a powerful model for studying mechanosensory hair cell regeneration. We have developed a chemical screen to identify FDA-approved drugs and biologically active compounds that modulate hair cell regeneration in zebrafish. Of the 1680 compounds evaluated, we identified two enhancers and six inhibitors of regeneration. The two enhancers, dexamethasone and prednisolone, are synthetic glucocorticoids that potentiated hair cell numbers during regeneration and also induced hair cell addition in the absence of damage. BrdU analysis confirmed that the extra hair cells arose from mitotic activity. We found that dexamethasone and prednisolone, like other glucocorticoids, suppress zebrafish caudal fin regeneration, indicating that hair cell regeneration occurs by a distinctly different process. Further analyses of the regeneration inhibitors revealed that two of the six, flubendazole and topotecan, significantly suppress hair cell regeneration by preventing proliferation of hair cell precursors. Flubendazole halted support cell division in M-phase, possibly by interfering with normal microtubule activity. Topotecan, a topoisomerase inhibitor, killed both hair cells and proliferating hair cell precursors. A third inhibitor, fulvestrant, moderately delayed hair cell regeneration by reducing support cell proliferation. Our observation that hair cells do not regenerate when support cell proliferation is impeded confirms previous observations that cell division is the primary route for hair cell regeneration after neomycin treatment in zebrafish.

\section{Introduction}

Mechanosensory hair cells of the inner ear allow vertebrates to sense sound and orient in space. Normal aging, genetic predispositions, prolonged or excessive exposure to high sound levels, environmental toxins, and some medications can readily induce damage or loss of hair cells, often leading to permanent hearing deficits and balance disorders. Mammals, including humans, have a full complement of hair cells at birth, but lack the capacity to regenerate lost hair cells (Roberson and Rubel, 1994; Oesterle and Stone, 2008; Warchol, 2010).

Replacement of damaged and dying sensory hair cells is robust in both developing and mature non-mammalian vertebrates (Cotanche, 1987; Cruz et al., 1987; Corwin and Cotanche, 1988; Jørgensen and Mathiesen, 1988; Ryals and Rubel, 1988; Stone and Cotanche, 2007; Edge and Chen, 2008; Brignull et al., 2009). Candidate molecules have been assessed for their role in hair cell regeneration, including Atoh1, members of the Notch signaling pathway, p2 ${ }^{\mathrm{Kip} 1}$, Rb, and TGF- $\alpha$ (Chen and Segil, 1999; Löwenheim et al., 1999; Stone and Rubel, 1999; Zheng and Gao, 2000; Li et al., 2003; Izumikawa et al., 2005; Sage et al., 2005, 2006; Cafaro

Received July 28, 2011; revised Dec. 23, 2011; accepted Jan. 12, 2012.

Author contributions: K.N.O., D.W.R., and E.W.R. designed research; P.N., K.E.R., and K.N.O. performed research;

P.N., K.E.R., K.N.O., D.W.R., and E.W.R. analyzed data; P.N., K.N.O., D.W.R., and E.W.R. wrote the paper.

This work was supported by Action on Hearing Loss, and National Institute on Deafness and Other Communication Disorders Grants DC04661 and DC011269.

The authors declare no competing financial interests.

Correspondence should be addressed to Edwin W Rubel, Virginia Merrill Bloedel Hearing Research Center, Box 357923, University of Washington, Seattle, WA 98195. E-mail: rubel@uw.edu.

DOI:10.1523/JNEUROSCI.3905-11.2012

Copyright $\odot 2012$ the authors $\quad 0270-6474 / 12 / 323516-13 \$ 15.00 / 0$ et al., 2007; Breuskin et al., 2008; Collado et al., 2008; Oesterle and Stone, 2008; Brigande and Heller, 2009; Groves, 2010). However, many questions remain about the precise pathways responsible for initiating, maintaining and limiting hair cell regeneration in non-mammalian vertebrates, and correspondingly, what molecular pathways prevent regeneration of hair cells in the mammalian inner ear.

To identify novel and unexplored pathways that can regulate hair cell regeneration, we undertook a chemical screen for modulators of hair cell regeneration using zebrafish lateral line neuromasts as a platform. Zebrafish larvae have been used in many high-throughput drug-screening assays for studying cell death and regeneration (Fleming et al., 2005; Ton and Parng, 2005; Mathew et al., 2007; Coffin et al., 2010; Oppedal and Goldsmith, 2010; Ou et al., 2010). The hair cells located within neuromasts of the zebrafish lateral line system share structural and molecular similarities with mammalian inner ear hair cells (Whitfield, 2002; Nicolson, 2005; Brignull et al., 2009). Like mammalian hair cells, zebrafish hair cells are sensitive to damage from ototoxic drugs such as aminoglycoside antibiotics. Unlike mammals, zebrafish have the capacity to renew the full complement of hair cells within $72 \mathrm{~h}$ (Williams and Holder, 2000; Harris et al., 2003; Hernández et al., 2006; López-Schier and Hudspeth, 2006; Ma et al., 2008). The ability to directly visualize lateral line hair cells and manipulate environmental exposure in concert with an array of genetic tools and high fecundity makes the zebrafish lateral line a useful system for understanding hair cell regeneration.

We have developed a chemical screen that takes advantage of neuromasts in the larval zebrafish lateral line system to evaluate FDA-approved drugs and bioactives for modulators of hair cell 
A

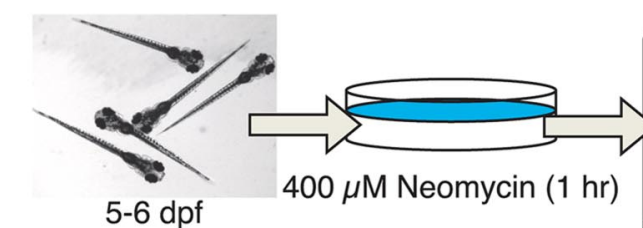

$\operatorname{Tg}($ pou4f3:gap43-GFP) larvae

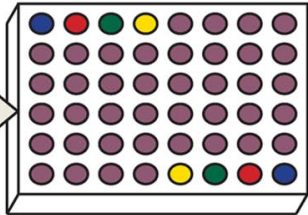

Incubate in drug (48 hr)
40 chemicals/plate - NINDS Custom Collection II - Enzo FDA-Approved

no neomycin, no drug

neomycin, no drug

neomycin, DMSO

neomycin, DAPT
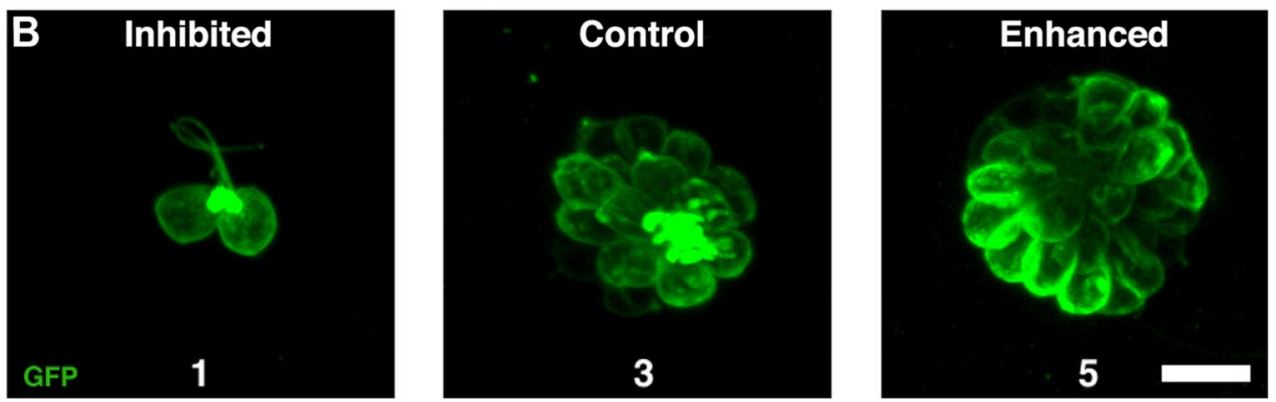

Figure 1. Chemical screening protocol for modulators of hair cell regeneration. A, Schematic diagramming the regeneration screen. Five to $6 \mathrm{dpf}$ Tg(pou4f3:gap43-GFP) zebrafish expressing membrane-bound GFP under the pou4f3 promoter were treated with $400 \mu \mathrm{m}$ neomycin for $1 \mathrm{~h}$, rinsed and transferred into 48 -well plates. Fish were then either treated for $48 \mathrm{~h}$ with a test drug, DMSO vehicle, or DAPT (a positive control for enhanced hair cell regeneration) and subsequently scored for GFP + hair cells on a $1-5$ scale, with a score of 3 representing normal regeneration. $\boldsymbol{B}$, Fluorescent images of the $\mathrm{MI}_{1}$ neuromasts illustrate the scoring scale used in the screen for regeneration modulators. Examples from $\mathrm{Tg}($ pou4f3:gap43-GFP) larval zebrafish that would have received a score of 1,3 , and 5 are shown. Scale bar, $10 \mu \mathrm{m}$.

regeneration. Two drugs were found to enhance hair cell regeneration while six others retarded regeneration. We report doseresponse relationships and experiments to assess the targets and the mechanisms by which these drugs modulate hair cell regeneration.

\section{Materials and Methods}

Zebrafish. Adult zebrafish were housed and maintained at $28.5^{\circ} \mathrm{C}$ in the University of Washington zebrafish facility (Westerfield, 1995). All zebrafish procedures and protocols were approved by the University of Washington Animal Care and Use Committee. Zebrafish embryos were obtained from paired matings and raised at $28.5^{\circ} \mathrm{C}$ in fish embryo me$\operatorname{dium}\left(\mathrm{EM} ; 1 \mathrm{~mm} \mathrm{MgSO}{ }_{4}, 150 \mu \mathrm{M} \mathrm{KH}_{2} \mathrm{PO}_{4}, 4 \mu \mathrm{M} \mathrm{Na}_{2} \mathrm{HPO}_{4}, 1 \mathrm{~mm} \mathrm{CaCl}\right.$, $500 \mu \mathrm{M} \mathrm{KCl}, 15 \mathrm{~mm} \mathrm{NaCl}$, and $714 \mu \mathrm{M} \mathrm{NaHCO}_{3}$ in $\mathrm{dH}_{2} \mathrm{O}$ ). Larvae were kept at a density of 50 animals per $100 \mathrm{~mm}^{2}$ Petri dish in $\sim 30 \mathrm{ml}$ of EM. At 4 days post-fertilization ( $\mathrm{dpf}$ ), larvae were fed live rotifers and dry food, and then transferred into fresh EM. For our experiments, in addition to the wild-type ${ }^{*} \mathrm{AB}$ strain, we used $\mathrm{Tg}$ (pou4f3:gap43-GFP) zebrafish, a transgenic line that endogenously expresses green fluorescent protein (GFP) in both immature and mature hair cells of the lateral line and inner ear under the control of the pou 4 f3 ( brn $3 c$ ) promoter (courtesy of H. Baier, University of California-San Francisco, San Francisco, CA). In these fish, GFP is targeted to the plasma membrane with a GAP-43 membrane targeting sequence (Xiao et al., 2005).

Drug libraries. Two drug libraries were used: the NINDS Custom Collection II (Microsource) and the FDA-approved drug library (Enzo LifeSciences). The NINDS library consists of 1040 drugs and bioactive compounds dissolved in dimethylsulfoxide (DMSO) at $10 \mathrm{~mm}$ concentration. Some drugs in this library are not FDA-approved, but all have known biological activity. The Enzo library contains 640 FDA-approved compounds dissolved in DMSO at $2 \mathrm{mg} / \mathrm{ml}$, all of which have confirmed and well characterized bioactivity. The identities of the individual compounds were blinded during the primary and confirmatory screens.

Primary screening protocol. Larvae from $\mathrm{Tg}$ (pou4f3:gap43-GFP) heterozygote crosses were collected and initially screened for GFP expression in hair cells at $2 \mathrm{dpf}$. At 5-6 dpf, all free-swimming larvae (except untreated controls; see below) were treated with $400 \mu \mathrm{M}$ neomycin sulfate (Sigma, catalog \#N1142) in EM for $1 \mathrm{~h}$ and immediately rinsed four times in fresh EM (Harris et al., 2003; Murakami et al., 2003; Santos et al.,
2006). Larvae were distributed using a wide-bore glass pipette into 48 well plates (Corning, catalog \#3338) at a density of 3 fish per well. The volume in each well was adjusted to $1 \mathrm{ml}$ with fresh EM. Each 48 -well plate contained 8 control wells and 40 experimental wells (Fig. 1A). The control wells included: fish that received no neomycin exposure and were subsequently held in drug-free EM (mock treatment; 2 wells); neomycintreated fish, subsequently held in drug-free EM (neomycin-only treatment; 2 wells); neomycin-treated fish, subsequently held in either $0.1 \%$ (control for NINDS library) or $0.2 \%$ (control for Enzo library) DMSO (neomycin + drug vehicle treatment; 2 wells); and neomycin-treated fish subsequently held in $50 \mu \mathrm{M}$ DAPT ( $N$-[N-(3,5-difluorophenacetyl)-Lalanyl]-( $S$ )-phenylglycine t-butyl ester), a $\gamma$-secretase inhibitor (positive control; 2 wells). DAPT has been previously shown to diminish Notch signaling by preventing cleavage and release of the Notch intracellular domain (Geling et al., 2002), which results in an increase in the number of zebrafish lateral line hair cells regenerated after neomycin exposure (Ma et al., 2008). Experimental drugs from the NINDS Custom Collection II library were diluted in EM to a final concentration of $10 \mu \mathrm{M}$ drug in $0.1 \%$ DMSO. Drugs from the Enzo FDA-approved drug library were diluted to a final concentration of $4 \mu \mathrm{g} / \mathrm{ml}$ in $0.2 \%$ DMSO. While concentrations of drugs varied, $93 \%$ were between 1 and $20 \mu \mathrm{M}$ concentration and none had a concentration $>35 \mu \mathrm{m}$. Larvae were fed live rotifers $24 \mathrm{~h}$ after the neomycin treatment and monitored daily for general drug toxicity. After $48 \mathrm{~h}$ in the experimental drug, larvae were anesthetized in buffered $0.001 \%$ MS-222 (ethyl 3-aminobenzoate methanesulfonate; Sigma, catalog \#E10521) before observation and scoring.

Larvae were examined and scored under epifluorescent illumination using a $40 \times$ objective $(\mathrm{NA}=0.75)$ on a Zeiss Axioplan 2 ie epifluorescence microscope. Each fish was scored for degree of neuromast hair cell regeneration on a scale from 1 to 5 (Fig. $1 B$ ), with 1 being greatly reduced or absent regeneration, 3 indicating normal regeneration as seen in drugfree and DMSO controls, and 5 being excessive regeneration, such as that seen with DAPT treatment. At least eight neuromasts per fish were evaluated before assigning a score and three or more fish were scored per drug. To control for variation between experiments, scores for each round of screening experiments were calibrated to the DMSO controls in that experiment. All scoring was performed by the same investigator.

Drugs (hereafter termed "regeneration modulators") with average scores $\geq 3.5$ were considered putative enhancers of regeneration while 
drugs with average scores $\leq 2.5$ were considered putative inhibitors of regeneration. All regeneration modulators were retested twice following an identical protocol to verify the effect of the modulator on regeneration. Drugs that consistently had high or low scores across the three replicates (initial screen + two rescreens) were established as putative "hits" and further tested.

Regeneration modulators that caused a reduction in the number of regenerated hair cells (inhibitors) were tested for hair cell toxicity. To discriminate between inhibition of hair cell regeneration and toxicity, three larvae were treated with only the inhibitor for $48 \mathrm{~h}$ (no prior neomycin-induced hair cell death) at the same concentrations as in the primary screen. Fish were then anesthetized and scored as before.

Dose-response functions. We next assessed the dose-response relationships of all putative regeneration modulators to determine the lowest concentration that produced the maximum modulation effect. Wildtype ${ }^{\star} \mathrm{AB}$ larval zebrafish (5-6 dpf) were treated with $400 \mu \mathrm{M}$ neomycin for $1 \mathrm{~h}$ and rinsed 4 times in fresh EM. Groups of 10-12 neomycintreated larvae were then transferred by Netwell baskets (Corning, catalog \#3480) into separate wells of a 6-well plate containing concentrations of experimental drug, ranging from 0.1 to $100 \mu \mathrm{M}$, for $48 \mathrm{~h}$ at $28.5^{\circ} \mathrm{C}$. To standardize the DMSO concentration among the different test drug concentrations, DMSO concentrations were (with 1 exception) adjusted to $1.0 \%$ for all conditions. The exception was topotecan, which is not soluble in DMSO; hence, topotecan was dissolved in water. DAPT treatment and no-drug treatment controls were also evaluated in each experiment.

For rapid assessment, lateral line hair cells were labeled with the fluorescent vital dye DASPEI (2-(4-(dimethylamino)styryl)- $N$ ethylpyridinium iodide; $0.005 \%$ final concentration in EM; Invitrogen, catalog \#D426) for 15 min (Harris et al., 2003; Murakami et al., 2003; Owens et al., 2008, 2009; Coffin et al., 2009). Larvae were then rinsed twice in fresh EM, anesthetized and visualized using a Leica MZFI111 epifluorescent dissecting microscope equipped with a DASPEI filter set (excitation 450-490 nM and barrier 515; Chroma Technologies). Ten neuromasts were evaluated per fish: supraorbital $\left(\mathrm{SO}_{1}, \mathrm{SO}_{2}\right)$, infraorbital $\left(\mathrm{IO}_{1-4}\right)$, mandibular $\left(\mathrm{M}_{2}\right)$, middle $\left(\mathrm{MI}_{1}, \mathrm{MI}_{2}\right)$, and otic $\left(\mathrm{O}_{2}\right.$; Raible and Kruse, 2000). Each was assigned a score of 0-2: 0 (little/no staining), 1 (reduced staining), and 2 (normal staining) for a combined score between 0 and 20 per fish. Eight to 12 fish were assessed for each condition and scores were averaged for each group $( \pm 1 \mathrm{SD})$.

Hair cell immunohistochemistry. To count hair cells, Tg(pou4f3:gap43GFP) transgenic larvae were killed and fixed in $4 \%$ paraformaldehyde (PFA) in $0.1 \mathrm{M}$ PBS at $\mathrm{pH} 7.2$, overnight at $4^{\circ} \mathrm{C}$. After fixation, larvae were rinsed 3 times for $20 \mathrm{~min}$ in PBS with $0.1 \%$ Triton X-100 (PBS-T), washed for $30 \mathrm{~min}$ in distilled water, and incubated for $1 \mathrm{~h}$ with blocking solution ( $1 \%$ bovine serum albumin, $1 \%$ DMSO, and $0.02 \%$ sodium azide in PBS-T) plus 5\% normal goat serum to prevent nonspecific antibody binding. Larvae were subsequently held overnight in rabbit anti-GFP antibody (1:500 in blocking solution; Invitrogen, catalog \#G10362), rinsed 3 times for 20 min with PBS-T, and incubated for $5 \mathrm{~h}$ in a goat anti-rabbit IgG antibody conjugated with Alexa-488 (1:500 in blocking solution; Invitrogen, catalog \#A11008). Larvae were rinsed 3 times in PBS-T, mounted in 50\% glycerol/PBS on bridged coverslips and visualized with a Zeiss Axioplan 2ie epifluorescence microscope under a $40 \times$ objective $(\mathrm{NA}=0.75)$. GFP-positive hair cells were counted in seven neuromasts per fish $\left(\mathrm{MI}_{1-2}, \mathrm{O}_{1-2}, \mathrm{M}_{2}, \mathrm{IO}_{4}, \mathrm{OP}_{1}\right.$; Raible and Kruse, 2000) for 10 fish per group. Data are presented as mean summed hair cells in these seven neuromasts $( \pm 1 \mathrm{SD})$, compared with control fish maintained in the same conditions within the same experiment.

Cell proliferation labeling. To assess mitotic events in neuromasts of the lateral line during the first $24 \mathrm{~h}$ of the regeneration period, fish were co-treated with 5'-bromo-2'-deoxyuridine (BrdU; Sigma, catalog \#B5002) with and without each modulatory drug. Following neomycin exposure, larvae were simultaneously incubated with the optimal concentration of drug as determined in dose-response tests and $5 \mathrm{~mm} \mathrm{BrdU}$ in EM (adjusted to a $1 \%$ DMSO concentration) for $24 \mathrm{~h}$ (for inhibitors) or $48 \mathrm{~h}$ (for enhancers) at $28.5^{\circ} \mathrm{C}$. The fish were then killed, fixed in $4 \%$ PFA overnight at $4^{\circ} \mathrm{C}$, and rinsed several times in PBS-T. To visualize hair cells as well as BrdU incorporation, fish were first immunostained with rabbit anti-GFP and Alexa 488-conjugated goat anti-rabbit. BrdU immu- nohistochemical processing was then performed as described previously (Harris et al., 2003; Ma et al., 2008), with several modifications. Fixed larvae were rinsed three times for $20 \mathrm{~min}$ in PBDT (PBS, 1\% DMSO, $0.1 \%$ Tween 20 ). Due to the superficial nature of hair cells and neuromasts, methanol dehydration/rehydration and proteinase $\mathrm{K}$ were not used. Instead, samples were incubated with $1 \mathrm{~N}$ hydrochloric acid for $1 \mathrm{~h}$ at room temperature and rinsed 3 times in PBDT for $5 \mathrm{~min}$. Before the addition of antibodies, larvae were placed in blocking solution $(10 \%$ normal goat serum in PBDT) for $1 \mathrm{~h}$ at room temperature. Mouse antiBrdU (BD PharMingen, catalog \#555627) was used at a 1:250 dilution in blocking solution. Samples were then incubated in goat anti-mouse IgG secondary antibody conjugated with Alexa-568 (1:500 dilution in blocking solution; Invitrogen, catalog \#A11004). Larvae were finally rinsed several times in PBS-T and stored in $50 \%$ glycerol/PBS at $4^{\circ} \mathrm{C}$ before visualization.

To assess cells in M-phase, whole-mount immunohistochemistry was performed to detect phospho-histone H3 (Ma et al., 2008). Fish were placed in $400 \mu \mathrm{M}$ neomycin for $1 \mathrm{~h}$, rinsed 4 times in fresh EM, and treated with the optimal concentration of inhibitor drug (1\% DMSO adjusted) in EM for $24 \mathrm{~h}$ at $28.5^{\circ} \mathrm{C}$. Larvae were then anesthetized with MS-222, fixed in $4 \%$ PFA overnight at $4^{\circ} \mathrm{C}$ and rinsed several times for 20 min in PBS-T. Hair cell labeling was first performed using the rabbit anti-GFP antibody and Alexa 488-conjugated goat anti-rabbit IgG before immunostaining for phospho-histone H3. Larvae were then washed in distilled water for $30 \mathrm{~min}$, treated with $5 \%$ normal goat serum in blocking solution and incubated overnight with rat anti-phosphohistone $\mathrm{H} 3$ (ser10) primary antibodies (1:500 dilution in blocking solution; Millipore, catalog \#06-570). Following three washes with PBS-T for $20 \mathrm{~min}$, samples were labeled for $5 \mathrm{~h}$ with Alexa-568conjugated goat anti-rat IgG (1:500 dilution in blocking solution). Larvae were finally rinsed three more times in PBS-T and stored in $50 \%$ glycerol/PBS at $4^{\circ} \mathrm{C}$ before visualization.

For evaluating total cell numbers within neuromasts, ${ }^{\star} \mathrm{AB}$ wild-type zebrafish larvae were killed and fixed in $4 \%$ PFA overnight at $4^{\circ} \mathrm{C}$. After several rinses in PBS-T, fish were incubated in the pan-nuclear dye, SYTOX Green (1:10,000 in PBS-T; Invitrogen; catalog \#S7020), which stains nucleic acids with high-affinity, and therefore both hair cells and support cells. After $5 \mathrm{~min}$, larvae were rinsed several times in PBS-T and stored in $50 \%$ glycerol/PBS at $4^{\circ} \mathrm{C}$ before imaging.

Samples were mounted in 50\% glycerol/PBS on bridged coverslips and observed on a Zeiss LSM5 Pascal confocal microscope under a $40 \times$ objective $(\mathrm{NA}=1.3)$. Double-labeled cells were counted in seven neuromasts per fish $\left(\mathrm{MI}_{1-2}, \mathrm{O}_{1-2}, \mathrm{M}_{2}, \mathrm{IO}_{4}, \mathrm{OP}_{1}\right)$ and compared with values from vehicle-only control fish. Images were processed using ImageJ, Pas$\mathrm{cal}$, and Adobe Photoshop CS4 software. Counts are presented as mean total cell numbers per fish ( $\pm 1 \mathrm{SD})$. We calculated $t$ tests and ANOVA (one- and two-way) to evaluate statistical significance $(\alpha=0.05)$.

Caudal fin amputation. Wild-type ${ }^{*} \mathrm{AB}$ zebrafish embryos were dechorionated at 2-3 dpf, anesthetized with MS-222 and transferred to a glass depression slide. Using a surgical blade (Fine Science Tools, catalog $\# 10015-00$ and \#10007-12), the caudal fin primordia was amputated posterior to the notochord (Mathew et al., 2007). Larvae were then photographed under a Zeiss Axioplan 2 bright field microscope with a differential interference contrast filter using a $10 \times$ objective $(\mathrm{NA}=0.17)$ to document the point of amputation. Fish was then placed in individual wells of a 48 -well plate containing the optimal concentration of a modulator drug in $1 \mathrm{ml}$ of EM ( $1 \%$ DMSO adjusted) and allowed to recover at $28.5^{\circ} \mathrm{C}$ for $72 \mathrm{~h}$. Each fish was anesthetized with MS-222 and the caudal fin was re-imaged. Caudal fin regeneration was assessed by subtracting the distance from the caudal fin tip to the notochord immediately after amputation from that measurement at $72 \mathrm{~h}$ post-amputation. The caudal fin tip was defined as the point at the end of the fin directly along the midline from the notochord.

\section{Results}

\section{Rapid screening for modulators of hair cell regeneration}

Using the zebrafish lateral line system, we screened for novel drugs and small drug-like compounds that affect the rate or amount of hair cell regeneration (Fig. 1A). To induce regenera- 

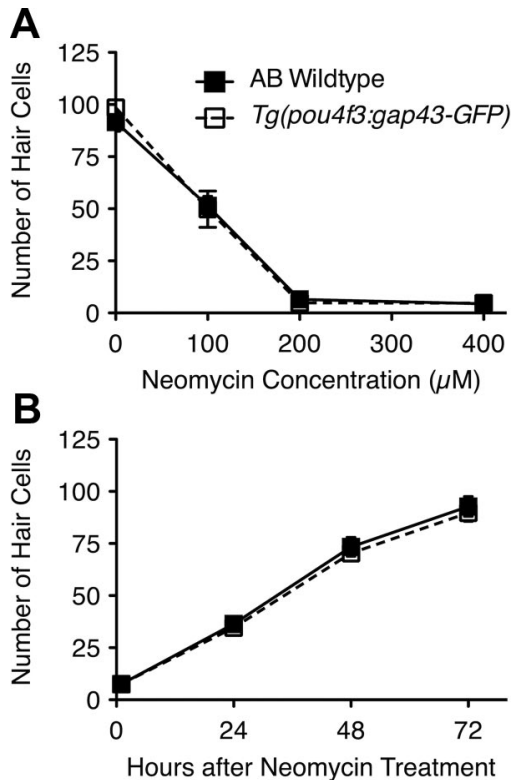

Figure 2. A, Hair cell death in $T g$ (pou4f3:gap43-GFP) fish is similar to that of ${ }^{*} A B$ wild-type fish. Five dpf zebrafish larvae were treated with 0, 100,200, or $400 \mu \mathrm{m}$ neomycin for $1 \mathrm{~h}$. Graph displays the mean total number of parvalbumin-labeled hair cells in seven neuromasts from each fish ( $n=10$ fish/group). $\boldsymbol{B}$, Hair cell regeneration in $\mathrm{Tg}$ (pou4f3:gap43-GFP) fish is similar to that of ${ }^{*} A B$ wild-type fish. Five dpf zebrafish larvae were treated with $400 \mu \mathrm{m}$ neomycin for $1 \mathrm{~h}$ and then held in EM for 1, 24, 48, or $72 \mathrm{~h}$. Graph displays the mean total number of parvalbumin-labeled hair cells in seven neuromasts of 10 fish for each group. Error bars indicate $\pm 1 \mathrm{SD}$.

tion, we exposed zebrafish larvae at $5 \mathrm{dpf}$ to $400 \mu \mathrm{M}$ neomycin for $1 \mathrm{~h}$, which kills $>90 \%$ of mature lateral line hair cells. Regeneration occurs rapidly in wild-type animals, reaching control levels within $\sim 72 \mathrm{~h}$ after aminoglycoside exposure (Williams and Holder, 2000; Harris et al., 2003; Murakami et al., 2003; LópezSchier and Hudspeth, 2006; Hernández et al., 2007; Ma et al., 2008). To facilitate visualization and assessment of regeneration, we used $T g$ (pou4f3:gap43-GFP) zebrafish, a transgenic line that expresses membrane-bound GFP in hair cells under the control of the pou $4 \mathrm{f} 3$ promoter. These animals are otherwise wild-type and show aminoglycoside-induced hair cell death (Fig. 2A) and regeneration comparable to control animals (Fig. $2 B$ ). To test whether a drug modulates regeneration, neomycin-treated animals were placed in 48-well plates and immediately exposed to test drug for a $48 \mathrm{~h}$ period. At $48 \mathrm{~h}$ post-treatment, we assessed the regeneration of hair cells of several anterior lateral line neuromasts. Larvae were assigned a score on a scale from 1 to 5 based on the degree of neuromast hair cell regeneration, with a score of 1 reflecting attenuated or absent regeneration, 3 representing normal regeneration as seen in drug-free and DMSO controls, and 5 indicating excessive regeneration (Fig. $1 \mathrm{~B}$ ).

Results from initial screening of the 1680 drugs in two custom libraries are shown in Table 1 . We identified 176 drugs as potential inhibitors of regeneration and 115 drugs as potential enhancers of regeneration. Similar "hit" rates were observed in the two libraries, with $18.2 \%(189 / 1040)$ and $15.9 \%(102 / 640)$ identified from the NINDS Custom Collection II and the Enzo FDAapproved library, respectively. During testing, 243 compounds from both libraries were determined to be lethal to fish. We did not assess whether lower concentrations of these drugs would allow animals to survive but affect hair cell regeneration. It should be noted that none of the compounds identified potentiated regeneration to the extent of that routinely seen with expo-
Table 1. Numerical results (and percentages) from the regeneration screen and subsequent rescreens

\begin{tabular}{|c|c|c|c|}
\hline Library & Initial screen & Rescreen & $\begin{array}{l}\text { Confirmed by dose- } \\
\text { response analysis }\end{array}$ \\
\hline \multicolumn{4}{|l|}{ NINDS Custom Collection II } \\
\hline Number of drugs evaluated & 1040 & 189 & 5 \\
\hline Number of putative enhancers ${ }^{a}$ & $86(8.3 \%)$ & $2(0.2 \%)$ & $2(0.2 \%)$ \\
\hline Number of putative inhibitors ${ }^{b}$ & $103(9.9 \%)$ & $3(0.3 \%)$ & 0 \\
\hline \multicolumn{4}{|l|}{ Enzo FDA-approved } \\
\hline Number of drugs evaluated & 640 & 102 & 45 \\
\hline Number of putative enhancers ${ }^{a}$ & $29(4.5 \%)$ & $8(1.3 \%)$ & 0 \\
\hline Number of putative inhibitors ${ }^{b}$ & $73(11.4 \%)$ & $37(5.8 \%)$ & $6(0.9 \%)$ \\
\hline
\end{tabular}

A matrix of the numerical results from the regeneration screen and subsequent rescreens. Listed are the numbers of putative enhancers and inhibitors identified in both the primary screen and subsequent rescreens.

${ }^{a}$ Putative enhancers average scored $\geq 3.5$.

${ }^{b}$ Putative inhibitors average scored $\leq 2.5$.

sure to DAPT; most of the putative enhancers were given a score between 3 and 4 based on our screening method, while the DAPT-treated fish reliably produced scores of 5 .

Our initial screen was designed to maximize sensitivity and thus we expected to have many false-positives and ideally few false-negatives for the drugs and concentrations tested. Each potential modulator of regeneration was tested twice more under the same conditions as described in the initial screen to assess reliability and thereby eliminate false-positives. We confirmed 10 compounds that putatively enhanced hair cell regeneration and 40 that putatively inhibited regeneration (Table 1). All putative modulatory drugs were then tested for ototoxicity in the absence of neomycin and a dose-response function was determined using a range of concentrations of each modulatory drug. From these validation experiments, we confirmed two drugs that reliably enhanced hair cell regeneration and six drugs that consistently inhibited regeneration (Table 2 ).

\section{The synthetic glucocorticoids dexamethasone and prednisolone enhance hair cell regeneration in a dose-dependent manner}

To find the lowest dose that produced the maximal modulation effect, we exposed larvae to varying concentrations of each enhancer drug for $48 \mathrm{~h}$ after $400 \mu \mathrm{M}$ neomycin treatment. Both dexamethasone and prednisolone induced a significant increase in regenerated hair cells relative to DMSO controls (Fig. 3). Analysis of these data with two-way ANOVA showed significant main effects of drug and concentration (control vs drug exposure), as well as an interaction effect $(p<0.001)$. Bonferroni post hoc tests indicated that the lowest concentration of prednisolone and dexamethasone that induced a significant increase in hair cells was $1 \mu \mathrm{M}(p<0.01$ and $p<0.001$ respectively). Beyond $5 \mu \mathrm{M}$, there was no additional increase in the number of hair cells with increasing dosage.

Each compound was also assessed for any noticeable effect in the absence of aminoglycoside-induced hair cell death. We found that both dexamethasone and prednisolone promoted hair cell addition in the absence of neomycin damage (Fig. $3 B, C$; squares). Larvae treated in dexamethasone or prednisolone for $48 \mathrm{~h}$ had more hair cells relative to DMSO vehicle controls at drug concentrations of $1 \mu \mathrm{M}$ or greater. The relative increase in the number of hair cells with exposure to either enhancer was similar to that seen after regeneration was induced by neomycin. A twoway ANOVA revealed significant main effects of drug and concentration (control vs drug exposure), as well as an interaction effect $(p<0.0001)$. The lowest concentration of prednisolone 
Table 2. Drugs that modulate hair cell regeneration, identified in screen and confirmed upon retesting

\begin{tabular}{|c|c|c|c|c|}
\hline Candidate drug & $\begin{array}{l}\text { Direction of } \\
\text { modulation }\end{array}$ & $\mathrm{EC}_{50}^{a}$ & $\begin{array}{l}\text { Optimal } \\
\text { range }^{b}\end{array}$ & Drug category; known activity \\
\hline Artesunate & Inhibitor & 5.39 & $5-10 \mu \mathrm{M}$ & Derivative of artemisinin; antimalarial treatment. \\
\hline Dexamethasone & Enhancer & 0.13 & $5-10 \mu \mathrm{m}$ & $\begin{array}{l}\text { Synthetic glucocorticoid; anti-inflammatory/immunosuppressant; treatment for autoimmune and } \\
\text { inflammatory conditions. }\end{array}$ \\
\hline Dipyridamole & Inhibitor & 1.07 & $5-50 \mu \mathrm{M}$ & Thromboxane synthase inhibitor; inhibits thrombus formation and induces vasodilation. \\
\hline Fenoprofen & Inhibitor & 5.81 & $10-50 \mu \mathrm{M}$ & $\begin{array}{l}\text { Nonsteroidal anti-inflammatory drug; inhibits cyclooxygenase activity and prostaglandin synthesis; } \\
\text { treatment for pain, swelling, and stiffness caused by osteoarthritis. }\end{array}$ \\
\hline Flubendazole & Inhibitor & 0.65 & $1-5 \mu \mathrm{M}$ & Benzimidazole anthelmintic; treatment of gastrointestinal parasites. \\
\hline Fulvestrant & Inhibitor & 3.25 & $5-10 \mu \mathrm{M}$ & $\begin{array}{l}\text { Selective estrogen receptor downregulator; treatment for hormone receptor-positive metastatic } \\
\text { breast cancer. }\end{array}$ \\
\hline Prednisolone & Enhancer & 0.58 & $5-10 \mu \mathrm{M}$ & $\begin{array}{l}\text { Synthetic glucocorticoid; anti-inflammatory/immunosuppressant; treatment of autoimmune and } \\
\text { inflammatory conditions. }\end{array}$ \\
\hline Topotecan & Inhibitor & 4.93 & $10-50 \mu \mathrm{M}$ & Topoisomerase I inhibitor; treatment of ovarian and lung cancer. \\
\hline
\end{tabular}

Confirmed modulatory drugs from our screening protocol that alter hair cell regeneration in zebrafish. Listed are the candidate modulatory drugs, their $\mathrm{EC}_{50}$ and optimal drug range, based on dose-response testing and previously characterized drug activity.

${ }^{a}$ Calculated from dose-response functions.

${ }^{b}$ optimal range is the drug dose that confers maximal change in regeneration (inhibition or enhancement) without noticeable toxicity to the fish.

and dexamethasone inducing a significant increase in hair cell numbers was again 1 $\mu \mathrm{M}(p<0.001$ and $p<0.001$ respectively; Bonferroni post hoc). Neither enhancer was toxic to hair cells at the concentrations tested $(0.1-50 \mu \mathrm{M})$.

\section{Dexamethasone- and prednisolone-} induced hair cells arise mitotically Increased numbers of regenerated hair cells can arise from enhanced hair cell precursor proliferation, promotion of differentiation of postmitotic precursors, transdifferentiation of other cells into new hair cells, or prevention of hair cell death. To help determine which of these possibilities occur, we assessed the incorporation of the thymidine analog, BrdU, during the $48 \mathrm{~h}$ regeneration period following neomycin-induced hair cell loss in the presence of dexamethasone or prednisolone. As Figure 4 illustrates, groups treated with $5 \mu \mathrm{M}$ dexamethasone or prednisolone showed an increase in the number of GFP+ hair cells compared with the DMSO vehicle control fish ( $t$ test; $p=0.011$ and $p=0.021$, respectively). There was a similar increase in the number of BrdU+ hair cells, suggesting that most of the regenerated hair cells arose from dividing precursors ( $t$ test; $p<0.001)$. In samples treated with BrdU and glucocorticoids only (no prior neomycin treatment), a significant increase in BrdU+ hair cells was noted in both dexamethasone and prednisolone-treated groups ( $t$ test; $p=0.0019$ and $p=0.0202$, respectively). These observations indicate that dexamethasone and prednisolone act by stimulating presumptive hair cell precursors to divide. We observed an increase of $\sim 1-4$ additional hair cells per neuromast, indicating that these glucocorticoids stimulate a $10-$ $25 \%$ increase in the number of hair cells in just $48 \mathrm{~h}$. These new hair cells may arise from either additional support cells entering the cell cycle, an interference with signaling that limits the number of hair cells produced during regeneration, or a faster cell cycle that allows a daughter cell to divide multiple times.
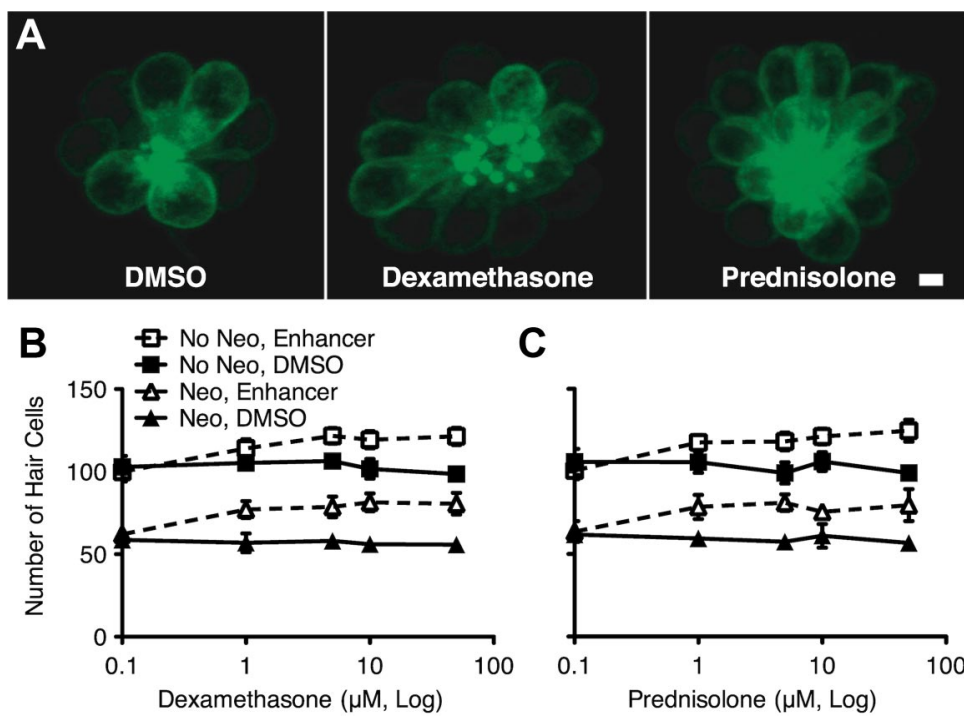

C

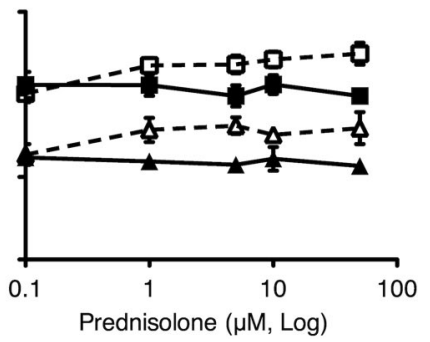

Figure 3. The glucocorticoids dexamethasone and prednisolone enhance hair cell regeneration. $\boldsymbol{A}$, Fluorescent confocal images of GFP + hair cells treated continuously for $48 \mathrm{~h}$ with DMSO vehicle (left), $5 \mu \mathrm{m}$ dexamethasone (middle) or $5 \mu \mathrm{m}$ prednisolone (right), after $400 \mu \mathrm{m}$ neomycin treatment for $1 \mathrm{~h}$. Scale bar, $2.5 \mu \mathrm{m} . \mathbf{B}, \mathbf{C}$, An increase in total number of hair cells occurs following exposure to either dexamethasone $(\boldsymbol{B})$ or prednisolone $(\boldsymbol{C})$. Graphs indicate the mean total number of GFP + hair cells among seven neuromasts from 10 fish after neomycin damage (triangles) or mock treatment (squares) and subsequent $48 \mathrm{~h}$ exposure to examethasone or prednisolone (open symbols and dotted lines) compared with DMSO vehicle-only (filled symbols and solid lines). Analysis by two-way ANOVA showed significant main effects of drug, concentration and an interaction for dexamethasone and prednisolone compared with DMS0 control fish in both neomycin and mock-treated groups. Error bars indicate $\pm 1 S D$.

Glucocorticoids inhibit zebrafish caudal fin regeneration

Studies on another zebrafish tissue capable of regeneration, the caudal fin, have shown that activation of the glucocorticoid receptor (GR) using exogenous glucocorticoids was sufficient to block regeneration following fin amputation (Mathew et al., 2007). Specifically, glucocorticoids were found to impair wound epithelium and blastema formation, as well as reduce proliferation of cells just beneath the plane of amputation in an inflammation-independent manner. To determine whether either dexamethasone or prednisolone have a similar effect, we performed a fin regeneration assay similar to that described by Mathew et al. (2007). Larvae were dechorionated at $2 \mathrm{dpf}$ and anesthetized. We then amputated their caudal fins and photographed them before exposure to glucocorticoids (Fig. 5A). After $3 \mathrm{~d}$ with or without glucocorticoid treatment, the caudal fins 
A

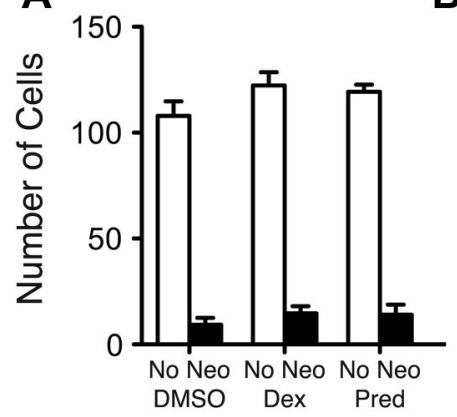

B

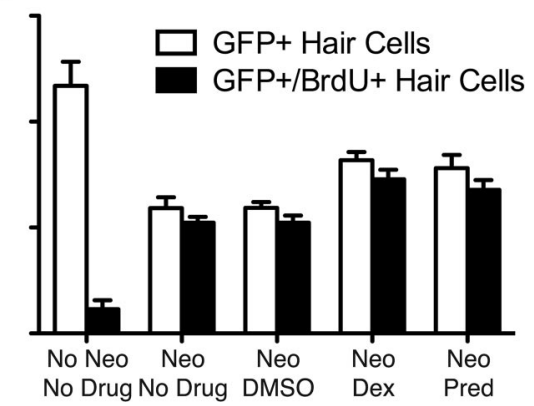

Figure 4. Dexamethasone and prednisolone potentiate support cell proliferation. $\boldsymbol{A}$, In fish co-treated with $5 \mu$ m dexamethasone (Dex) or prednisolone (Pred) and BrdU without prior neomycin treatment (№ Neo), there is an increase in the number of GFP-positive cells $(p<0.0001)$ and a comparable increase in the number of GFP $+/ \operatorname{BrdU}+$ hair cells $(p<0.01)$, suggesting that the increase in hair cells arose from support cell proliferation and differentiation of new hair cells. $\boldsymbol{B}$, In larvae treated with $400 \mu \mathrm{m}$ neomycin (Neo) and then allowed to recover in $5 \mu \mathrm{m}$ dexamethasone or prednisolone for $48 \mathrm{~h}$ in the presence of BrdU, there was a significant increase of GFP-labeled hair cells $(p<0.0001)$ and a comparable increase in BrdU-labeled hair cells $(p<0.0001)$ for dexamethasone and prednisolone-treated groups compared with DMSO vehicle controls. Means of total hair cells in seven neuromasts per fish ( $n=10$ fish/group) are presented. Error bars indicate $1 \pm S D$.

were reimaged to assess regeneration (Fig. 5B). Tail fin regeneration was quantified as additional distance from the fin tip directly midline to the notochord of the regenerated fin compared with fin distance directly after amputation. In our hands, two of the strongest inhibitors from Mathew et al. (2007), beclomethasone and clobetasol, severely inhibited regeneration at a concentration of $5 \mu \mathrm{M}$ (Fig. $5 C, E$ ). A characteristic $\mathrm{V}$-shaped fin was always observed. Dexamethasone and prednisolone also produced a strong inhibitory affect at $5 \mu \mathrm{M}$ (Fig. $5 D, E)$, though to a somewhat lesser degree than beclomethasone and clobetasol. These results suggest but do not prove that dexamethasone and prednisolone inhibit fin regeneration via the GR pathway. Interestingly, in one regenerative tissue, the caudal fin, dexamethasone and prednisolone inhibit regeneration, while in another, the lateral line, they enhance regeneration. This hints that there may be mechanistic differences in regeneration and may reflect a difference in the cell types responsible for regeneration of these two tissues.

\section{Testing putative inhibitors of regeneration for hair cell toxicity}

A decrease in the number of regenerated hair cells might occur from impairment of proliferation, delay or inhibition of hair cell differentiation, or death of newly generated hair cells. To differentiate between inhibition of hair cell regeneration and toxicity, we tested each putative inhibitor in the absence of neomycin. All three inhibitors identified in the NINDS library (Table 1) showed significant hair cell toxicity in the absence of neomycin treatment. Of the 37 inhibitors identified from the Enzo FDAapproved drug library, 21 were toxic. Since these drugs do not affect regeneration, per se, no further tests were conducted using these compounds. However, these drugs may provide new tools to evaluate hair cell death.

\section{Dose-response relationships of regeneration inhibitors}

Drugs identified as hair cell regeneration inhibitors that were not overtly toxic to hair cells were more thoroughly tested for dosedependent effects. Six of these drugs significantly inhibit hair cell regeneration in a concentration-dependent manner (Fig. 6). We observed two general dose-response profiles: moderate (e.g., fenoprofen) and severe inhibition (e.g., flubendazole). Several drugs showed additional hair cell toxicity or overall lethality at concentrations $>50$ $\mu \mathrm{M}$. The lowest concentration of drug that induced the maximal inhibition of regeneration without direct toxicity was used for further experiments (Table 2). Of the 6 regeneration inhibitors identified, the two strongest were flubendazole and topotecan. These drugs reduced hair cell regeneration by $77 \%$ and $64 \%$ of controls at 5 and $50 \mu \mathrm{M}$ concentrations, respectively. Fulvestrant, a moderate inhibitor, reduced hair cell regeneration by $46 \%$ at a concentration of $10 \mu \mathrm{M}$. Flubendazole, topotecan, and fulvestrant, two strong and one moderate inhibitor of regeneration, were further pursued for more thorough characterization.

\section{Hair cell regeneration is halted by topotecan and flubendazole and delayed by fulvestrant}

Drugs that inhibit hair cell regeneration may alter regeneration by preventing proliferation, delaying parts of the process, preventing cell maturation, or promoting hair cell or hair cell progenitor death. During our screening and dose-response experiments, we analyzed hair cell regeneration only at $48 \mathrm{~h}$ post-treatment. To more precisely define when regeneration inhibitors act, we evaluated the effects of inhibitors on hair cell replacement over a $72 \mathrm{~h}$ time-span. As demonstrated in Figure 7 , both $5 \mu \mathrm{M}$ flubendazole and $10 \mu \mathrm{M}$ topotecan were strong inhibitors of regeneration throughout the $72 \mathrm{~h}$ period tested; few to no GFP + hair cells were observed in neuromasts at any of the time points evaluated. In the absence of neomycin treatment, flubendazole showed little hair cell toxicity before $72 \mathrm{~h}$, after which there was a slight but significant decrease in hair cell numbers $(p<0.01$; Fig. $7 A)$. Topotecan alone began noticeably killing hair cells after 48 h of treatment, with complete hair cell death by $72 \mathrm{~h}$ (Fig. $7 B$ ). The inhibitory effects of topotecan are noticeable within $24 \mathrm{~h}$ of regeneration after neomycin treatment, while the overall toxicity of the drug does not take noticeable effect until $48 \mathrm{~h}$, suggesting that this drug does indeed inhibit the machinery involved in regeneration. Thus, flubendazole seems to act predominantly on the process of regeneration while topotecan may block regeneration through two modes, one that occurs early in the regeneration process and perhaps later on as well, affecting hair cell differentiation or mature hair cells. In samples treated with 5 $\mu \mathrm{M}$ fulvestrant, hair cell regeneration does occur but there is a slight decrease or delay in the number of hair cells produced at 48 and 72 h (Fig. 7C). Analysis of these data by two-way ANOVA yielded significant main effects of group and time, and a significant interaction (all $p$ values $<0.0001$ ). Pairwise comparisons (Bonferroni) yielded highly significant decreases in hair cell production by fulvestrant at 48 and $72 \mathrm{~h}$ of recovery following neomycin exposure (Fig. 7C; $p<0.001$, regeneration; filled and open triangles) and a marginally significant decrease in hair cell numbers due to fulvestrant treatment at $72 \mathrm{~h}$ in groups not receiving prior neomycin treatment (normal neuromast growth; filled and open squares in Fig. 7C; $p<0.05)$. 
Impact of inhibitors on proliferation We next determined whether flubendazole, topotecan, and fulvestrant affect proliferation during regeneration. After neomycin exposure, fish were allowed to recover for $24 \mathrm{~h}$ in EM containing $5 \mu \mathrm{M}$ BrdU and the inhibitor. Previous studies indicate that the majority of support cell proliferation begins soon after exposure to neomycin and the majority of new hair cells arise from mitotic events within $24 \mathrm{~h}$ of neomycin exposure (Harris et al., 2003; $\mathrm{Ma}$ et al., 2008). Following the $24 \mathrm{~h}$ incubation period, we assessed the number of $\mathrm{GFP}+$ cells, GFP $+/ \mathrm{BrdU}+$ cells and GFP-/BrdU + cells in seven neuromasts of 10 fish per group (Fig. 8). GFP-/ BrdU + cells were presumed to be dividing support cells. Hair cell counts in the absence of neomycin-induced regeneration were not affected by $5 \mu \mathrm{M}$ flubendazole or fulvestrant, but significantly diminished with $10 \mu \mathrm{M}$ topotecan ( $t$ test; $p<0.001$; Fig. $8 B$, compare white bars between No Neo groups with and without inhibitor). Notably, some GFP - cells incorporated BrdU in and around the neuromast of mock-treated controls, indicating that ongoing cell division is occurring in the absence of damage (Fig. 8, black bars in No Neo groups without inhibitor). However, there is a six-fold decrease in the number of GFP-/BrdU+ cells with either flubendazole or topotecan, showing that both drugs dramatically inhibit division of at least a subset of the support cells in the absence of damage to hair cells ( $t$ test; $p<$ 0.0001 ; compare black bars in No Neo groups with and without inhibitor). Samples treated with fulvestrant without prior neomycin-induced damage showed no significant change in the number of GFP-/ $\mathrm{BrdU}+$ cells when compared with controls.

In fish treated with neomycin and allowed to recover in vehicle only (DMSO or embryo media) for $24 \mathrm{~h}$, we see many newly formed GFP+ hair cells (Fig. 8, white bars between Neo groups). Of these cells, the majority are $\mathrm{BrdU}+$, indicating they arose from proliferating support cells (Fig. 8, compare white bars to striped bars). In flubendazole and topotecan-treated groups, fewer hair cells arise and virtually none of these hair cells are labeled with BrdU. The number of these $\mathrm{GFP}+/ \mathrm{BrdU}-$ hair cells is consistent with the number of immature, neomycin-insensitive hair cells expected (Murakami et al., 2003; Santos et al., 2006). Notably, there is a substantial decrease in GFP-/BrdU+ support cells. We do not observe a repopulation of GFP + hair cells that are BrdU - in the presence of these mitotic inhibitors after neomycin treatment.

In fulvestrant-treated groups, most of the GFP + hair cells that regenerated after $24 \mathrm{~h}$ are also $\mathrm{BrdU}+$, similar to control groups (Fig. 8C, compare white bars to striped bars in neo groups). There is a slight decrease in support cell proliferation, seen as fewer GFP $-/$ BrdU + cells $(t$ test; $p<0.01)$. Thus, the mild decrease or

E
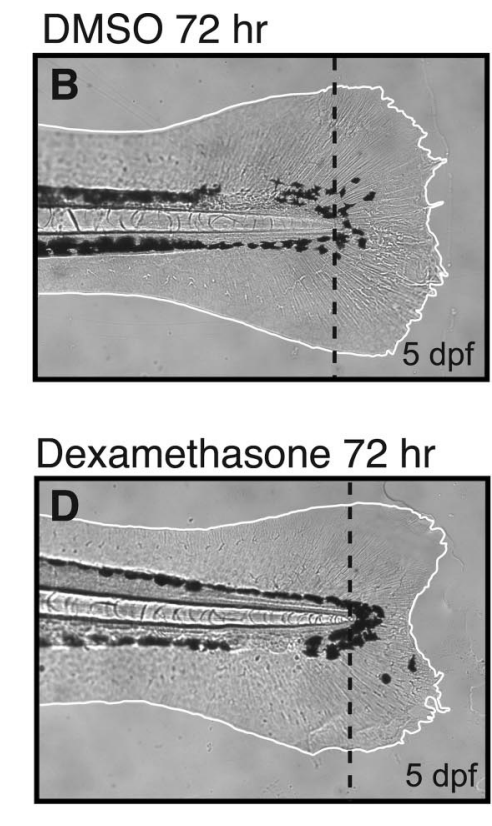

$5 \mathrm{dpf}$

dpf
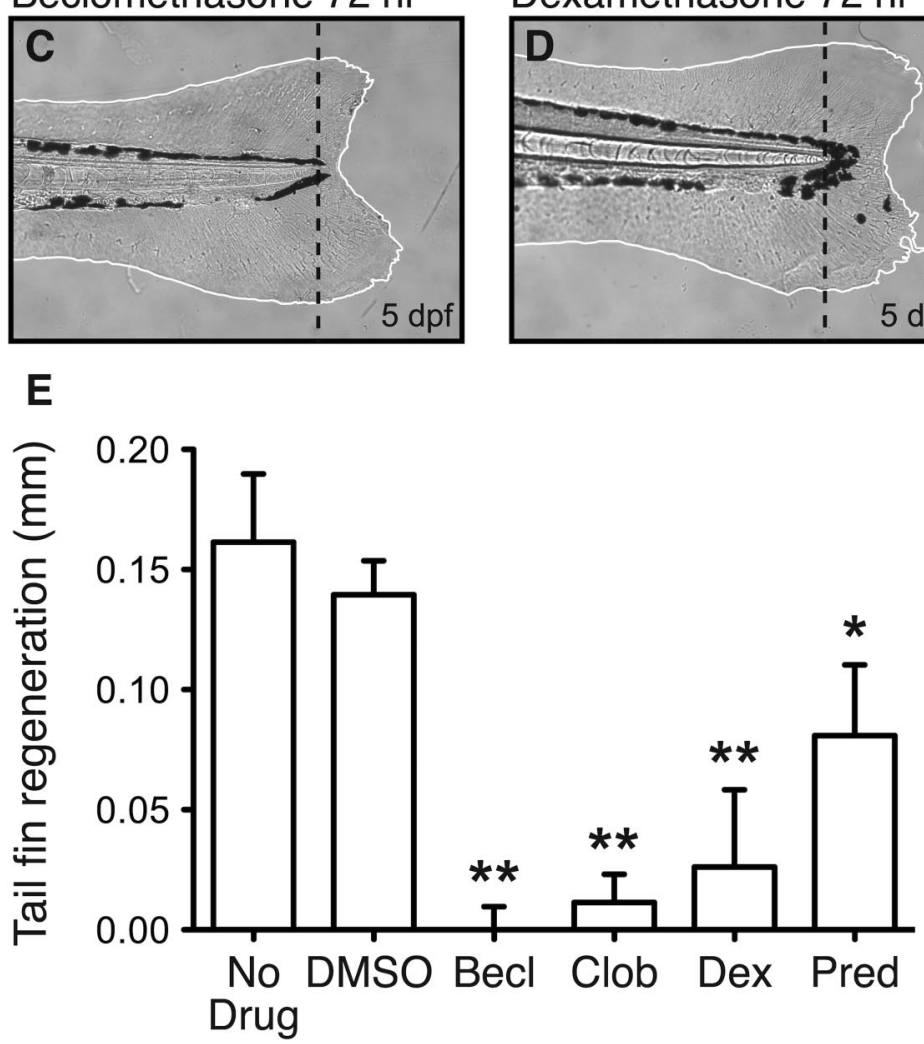

Figure 5. Dexamethasone and prednisolone suppress fin regeneration in zebrafish. Caudal fins of $2 \mathrm{dpf}$ zebrafish larvae were amputated and then exposed to glucocorticoids or left untreated in EM (or EM + DMSO) for $72 \mathrm{~h}$. A, Brightfield image displaying the caudal fin of a fish immediately after amputation. $\boldsymbol{B}-\boldsymbol{D}$, Brightfield images of caudal fin $72 \mathrm{~h}$ post-amputation when exposed concentration, significantly inhibit fin regeneration compared with vehicle controls ( $t$ test; Becl: ${ }^{* *} p<0.0001$; Clob: ${ }^{* *} p<$ 0.0001 ; Dex: ${ }^{* *} p<0.0001$; Pred: $\left.{ }^{*} p=0.0014\right)$. Five fins were examined per condition. Error bars indicate $1 \pm$ SD.

delay in hair cell regeneration in larvae treated with fulvestrant may be attributed to a moderate decrease in support cell division. The effects of fulvestrant on hair cell numbers may not occur until beyond the $24 \mathrm{~h}$ time-point.

To assess whether the inhibitors are overtly toxic to nondividing support cells within the neuromast, total cell counts were performed for each neuromast. Fish were exposed to inhibitor drugs for $48 \mathrm{~h}$ without prior neomycin treatment and subsequently labeled using the SYTOX Green nucleic acid stain. Examination with high-magnification confocal microscopy revealed no obvious DNA condensation or fragmentation within cells of the neuromast in any treatment or control group, nor was there any evidence of large gaps of missing cells. In particular, groups that were treated with inhibitor drugs in the absence of initial neomycin exposure did not exhibit significantly fewer cells than their mock-treated vehicle controls (data not shown). This 

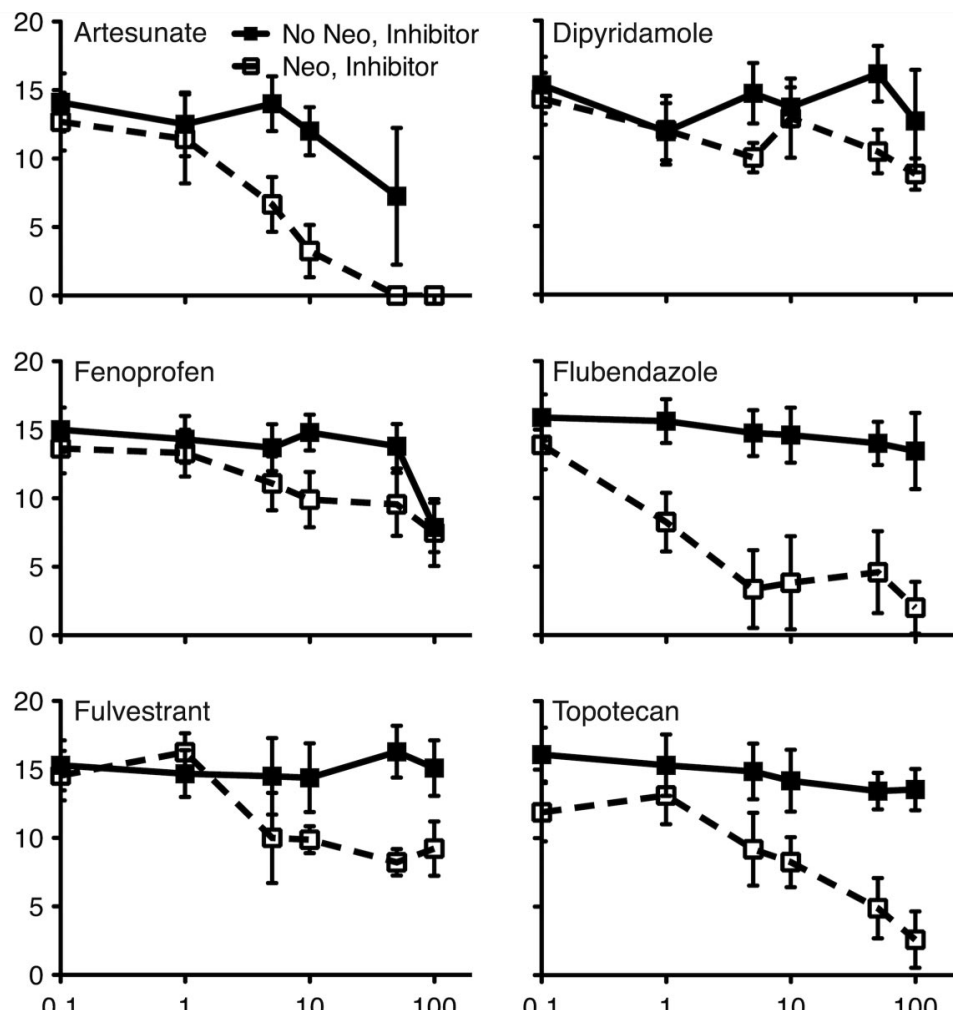

0.1

100

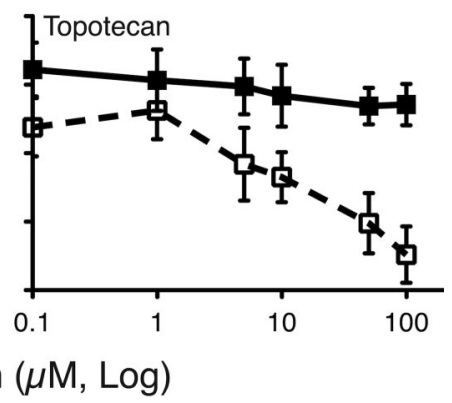

Figure 6. Dose-response functions for six confirmed regeneration inhibitors. Fish were acutely exposed to $400 \mu$ m neomycin (Neo) in embryo media for $1 \mathrm{~h}$ (or mock-treated; No Neo), and then incubated in $0,0.1,1,5,10,50$, and $100 \mu \mathrm{m}$ of the noted inhibitor drug in EM for $48 \mathrm{~h}$ during the regeneration period. Hair cell regeneration was assessed using the DASPEl scoring system. For each fish ( $n=10-12$ fish/group), 10 neuromasts were scored, and total DASPEl score was recorded. Means \pm 1 SD are shown. All six inhibitor drugs show significant suppression of hair cell regeneration over samples that received no neomycin treatment $(p<0.01)$. For both artesunate and fenoprofen, significant drug toxicity was noted in the mock-treated controls at high concentrations.

suggests that topotecan, flubendazole, and fulvestrant do not cause death of non-dividing support cells either alone at the concentrations used or during the $48 \mathrm{~h}$ after neomycin treatment.

\section{Recovery from inhibition}

While flubendazole and topotecan appear to prevent hair cell regeneration by affecting the mitotically active precursor cells destined to repopulate the neuromast with hair cells, it is not clear whether these drugs are halting cells in the cell cycle or actually killing precursors. To determine whether precursors can recover from inhibitor treatment, we exposed fish to inhibitor drugs for $24 \mathrm{~h}$ following neomycin treatment. We then rinsed the fish thoroughly and allowed recovery for up to an additional $72 \mathrm{~h}$. Hair cell counts were performed at 1, 24, 48, 72, and $96 \mathrm{~h}$ after onset of neomycin treatment (Fig. 9). Control larvae exhibit robust regeneration of hair cells with numbers that return to pretreatment levels between 72 and $96 \mathrm{~h}$ post-treatment. Incubation with flubendazole for $24 \mathrm{~h}$ initially blocks hair cell production, but robust regeneration resumes after inhibitor washout at a rate similar to control fish, though delayed (Fig. 9A). By contrast, topotecan has lasting effects on regeneration (Fig. 9B). As expected, no new hair cells were produced in fish treated with topotecan at $24 \mathrm{~h}$ after neomycin treatment. However, after topotecan was removed, hair cell regeneration was greatly attenuated, even $72 \mathrm{~h}$ after washout of the inhibitor (Fig. 9B, compare black and white triangles). Interestingly, treatment with topote- can alone for $24 \mathrm{~h}$ resulted in delayed loss of hair cells (Fig. 9B, white squares), suggesting that topotecan may kill maturing hair cells. It has yet to be determined whether topotecan kills dividing cells, newly formed hair cells, or both.

\section{Flubendazole arrests dividing cells in M-phase}

Previous literature suggests that flubendazole may inhibit microtubule assembly and function, resulting in cell cycle arrest (Cumino et al., 2009; Spagnuolo et al., 2010). To test this idea, fish from control and neomycin-treated groups were exposed to flubendazole for $24 \mathrm{~h}$ and then immunolabeled with phospho-histone H3 antibody (hereafter anti-PH3), a marker of cells in mitosis. While cells labeled with anti-PH3 were rare in control groups, we found a notable increase in the number of cells in $M$-phase with flubendazole ( $t$ test; $p<0.0001$; Fig. $10 A$ ). Fish exposed to flubendazole in the absence of neomycin-induced hair cell death also exhibited significantly more cells labeled with anti-PH3 ( $t$ test; $p<0.0001$ ), presumably halting those cells dividing in the process of normal neuromast growth. It should be noted that this effect of flubendazole was not limited to the neuromasts, as there were more anti-PH3labeled cells along the entire fish body after flubendazole treatment.

If flubendazole blocks hair cell regeneration primarily through cell cycle arrest, we hypothesized that it would only effectively block regeneration if larvae were treated during the peak of proliferation. Characterization of proliferative events during zebrafish hair cell regeneration has revealed a transient increase in support cells entering S-phase, peaking between 12 and $21 \mathrm{~h}$ after neomycin-induced hair cell death, and a peak in M-phase cells occurring 3-6 h later (Harris et al., 2003; Ma et al., 2008). We therefore exposed groups of neomycin-treated fish with flubendazole or DMSO vehicle alone for either $0-14,14-28$, or $28-42 \mathrm{~h}$ after neomycin treatment. All larvae were collected $48 \mathrm{~h}$ after the exposure to neomycin and immunolabeled for hair cells. As shown in Figure $10 \mathrm{~B}$, hair cell numbers were reduced only in fish treated with flubendazole between 14 and $28 \mathrm{~h}$ after neomycin treatment ( $t$ test; $p<0.0001$ ), further supporting the idea that flubendazole delays hair cell regeneration by arresting cells in M-phase.

\section{Discussion}

We used the inherent regenerative capacity of zebrafish lateral line hair cells to develop an efficient assay to screen through drug libraries for novel modulators of hair cell regeneration. While others have surveyed selected compounds that have potential to influence proliferation in mammalian vestibular epithelia (Montcouquiol and Corwin, 2001), this study represents the first broad chemical screen directed toward identifying compounds that alter hair cell regeneration. Two drug libraries composed of 1680 compounds yielded two enhancers and six inhibitors of 

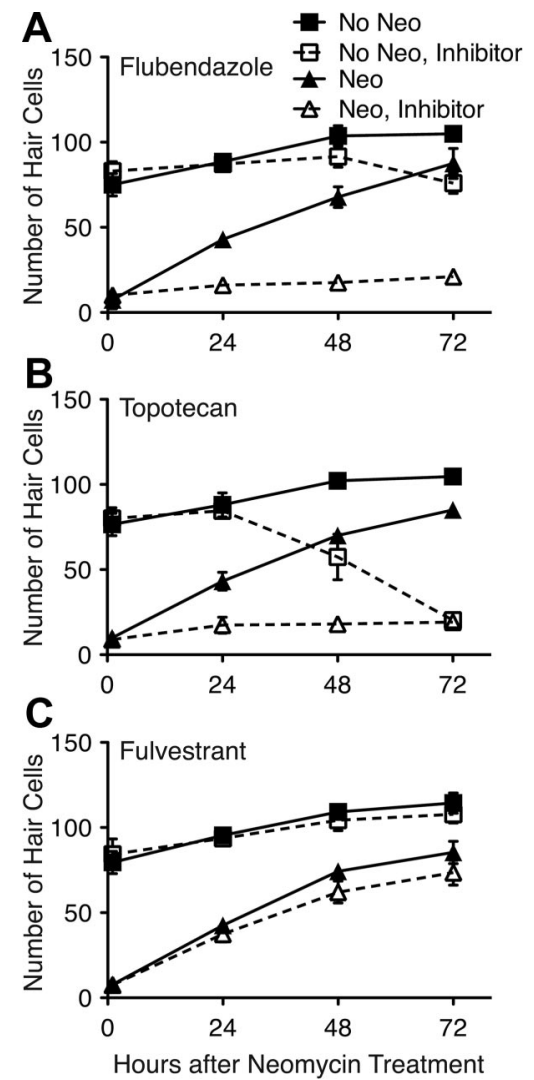

Figure 7. Hair cell regeneration is differentially suppressed during $72 \mathrm{~h}$ inhibitor exposure. Fish were treated with $400 \mu \mathrm{m}$ neomycin for $1 \mathrm{~h}$ (triangles) or mock-treated (squares), and allowed to recover in each inhibitor for $72 \mathrm{~h}$ (open symbols, dotted lines) or in vehicle (filled symbols, solid lines). GFP + hair cell counts were performed at 1, 24, 48, and $72 \mathrm{~h}$ following treatment. $A$, Fish treated with neomycin and subsequently with $5 \mu \mathrm{m}$ flubendazole (open triangles) displayed essentially no hair cell regeneration, while controls (filled triangles) showed complete recovery by $72 \mathrm{~h}$. Flubendazole alone (open squares) produce a small (and significant, $p<0.001$ ) decrease in total hair cell number at $72 \mathrm{~h}$ (filled squares). $\boldsymbol{B}$, Hair cell regeneration in fish treated with neomycin and then exposed to $10 \mu \mathrm{m}$ topotecan (open triangles) is also virtually totally suppressed relative to controls (filled triangles). In addition, treatment with topotecan in control fish causes toxicity at $48 \mathrm{~h}$ and beyond (open squares vs filled squares). C, $5 \mu$ m fulvestrant (open triangles) modestly reduced the number of regenerated hair cells versus controls (filled triangles) following neomycin pretreatment ( $p<0.01$ at 48 and $72 \mathrm{~h}$ after neomycin treatment). Fish treated with fulvestrant alone (open squares) did not show any significant hair cell loss relative to mock-treated controls (filled squares). For each group, seven neuromasts were examined ( $n=10$ fish). Error bars indicate \pm 1 SD.

regeneration, a $0.48 \%$ modulator compound "hit rate." Additionally, we identified 34 chemicals that were ototoxic over a $48 \mathrm{~h}$ incubation period (Table 1). Drugs were tested at concentrations between 1 and $35 \mu \mathrm{M}$. Our experience has shown that there is little toxicity at these concentrations (Ou et al., 2009). We anticipate that there are false-negatives among the drugs tested, that we overlooked compounds that would have altered hair cell regeneration at higher concentrations, and that compounds originally identified as lethal or toxic to hair cells may have modulated regeneration at lower concentrations.

We identified two compounds that enhanced regeneration. Dexamethasone and prednisolone are both synthetic glucocorticoids that regulate several physiological processes, including the immune response. Both drugs are thought to act primarily as anti-inflammatory agents, inhibiting macrophage activation and cytokine production (Isobe and Lillehoj, 1992; Hübner et al., 1996; Rhen and Cidlowski, 2005; Schaaf et al., 2009). Alteration of immune response might underlie their effects on hair cell re-

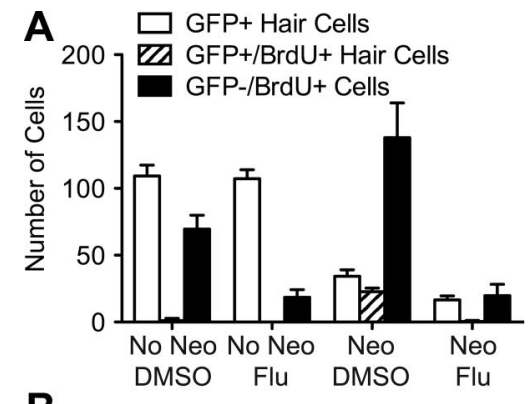

B
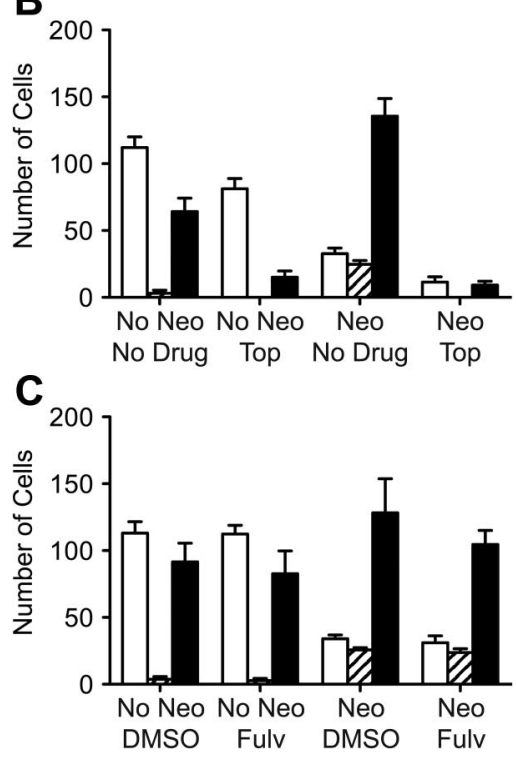

Figure 8. Inhibitor compounds prevent support cell division. Fish were treated with $400 \mu \mathrm{m}$ neomycin (or mock-treated) for $1 \mathrm{~h}$, and then exposed to $5 \mu \mathrm{m}$ BrdU plus inhibitor (5 $\mu \mathrm{m}$ flubendazole, $10 \mu \mathrm{m}$ topotecan, or $5 \mu \mathrm{m}$ fulvestrant) for $24 \mathrm{~h}$. At $24 \mathrm{~h}$ after neomycin treatment, animals were fixed and immunolabeled for hair cells and BrdU. $\boldsymbol{A}$, Fish mock-treated (No Neo) and then incubated in DMSO have virtually no GFP + /BrdU + hair cells, as is observed in fish mock-treated and exposed to flubendazole. The number of GFP-/BrdU + cells is greatly diminished between these groups suggesting that flubendazole is suppressing cell division in the absence of hair cell death. In fish treated with neomycin (Neo) and DMSO, significant regeneration is observed after $24 \mathrm{~h}$ (open bar), most of which are co-labeled with BrdU (striped bar). GFP-/BrdU + cell counts are substantially elevated (black bar), due to the fact that support cell division is occurring at a rapid pace to replace lost hair cells. In fish treated with neomycin and subsequently with flubendazole (Flu), significantly fewer hair cells are produced, and of those hair cells visible, almost none are labeled with BrdU. The number of BrdU-labeled support cells is dramatically reduced as well. $\boldsymbol{B}$, An almost identical pattern of GFP and BrdU labeling is observed in samples treated with topotecan (Top) as seen above. GFP - /BrdU + labeling is dramatically reduced in fish treated with topotecan, regardless of neomycin treatment, indicating that the drug is suppressing all cell divisions. After neomycin treatment and subsequent incubation in topotecan for $24 \mathrm{~h}$, there are significantly fewer hair cells regenerated, and of those few hair cells, none are co-labeled with BrdU. In mock-treated fish (No Neo), there is a noticeable decrease in the number of hair cells in fish exposed to topotecan, consistent with the idea that topotecan also kills mature hair cells. C, Mock-treated fish (No Neo) that were incubated in $5 \mu \mathrm{m}$ fulvestrant (Fulv) display an essentially identical pattern of GFP and BrdU labeling to mock-treated fish incubated in DMSO. There is no significant GFP + hair cell or GFP-/ BrdU + support cell loss between these groups. In fish treated with neomycin and later incubated in fulvestrant, GFP + hair cell and GFP + /BrdU + hair cell counts are similar to controls. However, GFP-/BrdU + cell counts in fulvestrant-treated groups were slightly diminished $(p<0.01)$ compared with DMSO controls. For each fish, seven neuromasts were examined ( $n=10$ fish/group). Error bars indicate \pm 1 SD.

generation. During tissue damage, leukocytes are recruited to sites of injury and play an important part in tissue repair. In birds, the resident population of leukocytes in the inner ear sensory epithelia increases after trauma, before the proliferation of hair cell progenitors (Warchol, 1997, 1999; Bhave et al., 1998; War- 


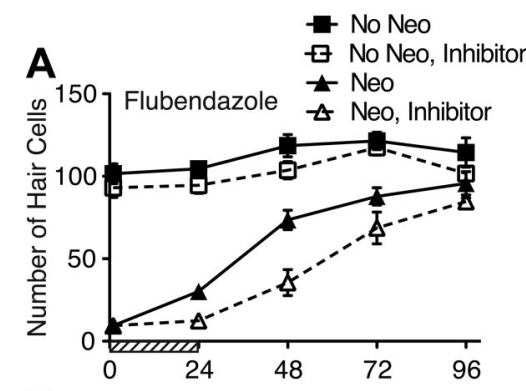

B

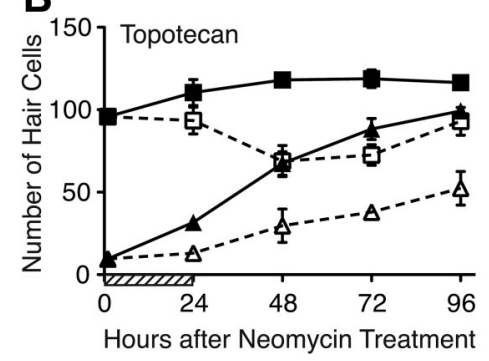

Figure 9. Flubendazole and topotecan arrest, but do not eliminate, hair cell regeneration. Fish were treated with neomycin, exposed to flubendazole or topotecan for $24 \mathrm{~h}$ (or mocktreated with DMSO; cross-hatched area on abscissa), and then placed in fresh embryo media for an additional 72 h. $\boldsymbol{A}$, Hair cell numbers in fish treated with flubendazole remain low while flubendazole is present (through $24 \mathrm{~h}$ ). When flubendazole was removed, hair cell regeneration resumes, and by $96 \mathrm{~h}$, hair cell numbers in flubendazole-treated and DMSO-treated controls are not significantly different. $\boldsymbol{B}$, Similar suppression of hair cell regeneration is seen in fish treated with topotecan for $24 \mathrm{~h}$. However, when the inhibitor drug was removed, hair cell regeneration was greatly attenuated. Hair cells were counted in seven neuromasts per fish ( $n=10$ fish per group). Error bars indicate \pm 1 SD.

chol et al., 2001; Oesterle et al., 2003; O'Halloran and Oesterle, 2004). Secretion of TGF- $\alpha$ and TNF- $\alpha$ by macrophages has been implicated in promoting the proliferation of avian utricular supporting cells after damage (Warchol et al., 2001). In contrast to our findings, the use of glucocorticoids was shown to reduce regenerative proliferation after hair cell lesions in birds (Warchol, 1999). In zebrafish, fin regeneration is severely inhibited by GR activation and expression of GR target genes (Mathew et al., 2007).

Our data suggest that dexamethasone and prednisolone may enhance hair cell regeneration in zebrafish by mechanisms other than immunosuppression. We observed that glucocorticoids promote an increase in hair cell numbers in the absence of neomycin exposure, demonstrating that they also affect hair cell addition independent of damage. Furthermore, other classes of anti-inflammatory compounds in our drug libraries, including nonsteroidal anti-inflammatory drugs, had no effect on hair cell regeneration. Dexamethasone and prednisolone may instead be acting on hair cell precursors directly. Since we see only a modest increase in hair cell numbers, it is possible that they act on a subset of precursors that are "primed" to divide. Alternatively, glucocorticoids may interfere with cessation of the regeneration process. While it is possible that glucocorticoids may act on immune cells to maintain hair cell numbers as a normal part of regeneration, this has not been observed in time-lapse imaging of hair cell regeneration after neomycin exposure (López-Schier and Hudspeth, 2006; Wibowo et al., 2011). Nevertheless, our data do not directly address the issue of immunosuppression. Whether the effects of dexamethasone and prednisolone on hair cells are due to GR activation is also unknown. Further studies will be needed to carefully explore these possibilities.

We find it surprising that so few enhancers of regeneration were identified in our screen. To date, the $\gamma$-secretase inhibitor
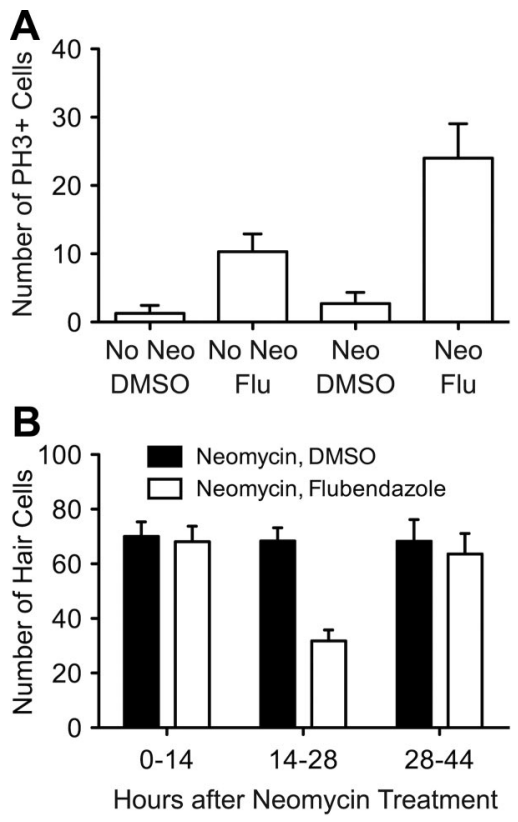

Figure 10. Flubendazole induces increased number of cells in M-phase. $\boldsymbol{A}$, Five dpf fish were either treated with $400 \mu \mathrm{m}$ neomycin (Neo) or mock-treated in embryo medium for $1 \mathrm{~h}$, and then exposed to flubendazole (Flu) or vehicle (DMSO) for $48 \mathrm{~h}$. Fish were immunostained with an antibody to phospho-histone $\mathrm{H} 3$ to assess the number of cells in M-phase at the time of death. Increased numbers of $\mathrm{PH} 3+$ cells are present in flubendazole-treated fish, regardless of whether native hair cells were killed by neomycin or not $(p<0.001)$ and more labeled cells were seen in neuromasts after neomycin treatment ( $\mathrm{NeO}$ ) than controls after flubendazole exposure. $\boldsymbol{B}$, Flubendazole reduces hair cell regeneration primarily between 14 and $28 \mathrm{~h}$ postdamage. Fish were treated with $400 \mu \mathrm{m}$ neomycin for $1 \mathrm{~h}$, and then treated with DMSO vehicle or $5 \mu \mathrm{m}$ flubendazole for one of three time periods $(0-14 \mathrm{~h}, 14-28 \mathrm{~h}$, or $28-44 \mathrm{~h}$ after neomycin). Larvae were then held in EM only for the remainder of time before fixation at $48 \mathrm{~h}$ and immunostained for GFP + hair cells. There is a marked decrease in the number of hair cells when proliferating cells are suspended in M-phase specifically during the $14-28 \mathrm{~h}$ incubation period after neomycin treatment, but not during other periods. For each fish, seven neuromasts were examined ( $n=10$ fish/group). Error bars indicate \pm 1 SD.

DAPT has been the only drug in zebrafish that is capable of producing excessively large increases in regenerated hair cells. DAPT works by interfering with Notch signaling, a pathway found to be important in regulating the number of hair cells regenerated in both fish and birds (Lanford et al., 1999; Stone and Rubel, 1999; Ma et al., 2008; Brigande and Heller, 2009; Daudet et al., 2009). The relative paucity of regeneration enhancers may reflect the composition of the libraries screened; interrogating a more diverse set of small molecules might reveal new compounds capable of promoting regeneration.

The inhibitors of hair cell regeneration identified from the primary and secondary screens are diverse in structure and function. We further characterized the inhibitors flubendazole, topotecan and fulvestrant. Flubendazole and topotecan produced the strongest inhibitory profile. Fulvestrant was selected as an example of one of the moderate inhibitors because of the drug's previously established pharmacological profile (Osborne et al., 2004).

Flubendazole is a benzimidazole antihelmintic that acts by binding to the colchicine-sensitive site of tubulin, thus inhibiting its polymerization or assembly into microtubules (Cumino et al., 2009; Spagnuolo et al., 2010). Flubendazole treatment of zebrafish larvae appears to arrest cells in M-phase, as indicated by increased staining with the phospho-histone $\mathrm{H} 3$ antibody. When flubendazole is removed, hair cell regeneration resumes, suggesting that its effects on microtubules are reversible. Since flubenda- 
zole reversibly arrests cell division, it appears that the signals controlling the hair cell regeneration process are maintained and promote full recovery after the delay. Flubendazole is very similar in structure to fenbendazole and albendazole, two drugs identified as ototoxic in our screen of the NINDS Custom Collection II library. It is interesting that subtle changes in structure or sidegroups produce markedly different effects.

The other strong inhibitor, topotecan, blocks regeneration almost completely, and repopulation of the neuromasts remains severely depressed for the entire period studied. Topotecan is a topoisomerase I inhibitor and is most commonly used as a chemotherapeutic agent. This drug is thought to act on tumor cells by stabilizing the covalent complex of topoisomerase I enzyme and strand-cleaved DNA, eventually inducing cell death (Kollmannsberger et al., 1999; Staker et al., 2002; Koster et al., 2007; Lorusso et al., 2010). This suggests that topotecan may act by killing the dividing support cells responsible for repopulating hair cells. Several authors have suggested that while a subset of support cells divide to give rise to new hair cells, another subset divide to replenish the depleted hair cell precursors (Jones and Corwin, 1996; López-Schier and Hudspeth, 2006; Ma et al., 2008). The delay in hair cell regeneration after topotecan is removed may reflect the time needed to restore the hair cell precursor population eliminated by topotecan treatment. It is also possible that topotecan does not wash out of cells readily, resulting in the observed delay.

Both flubendazole and topotecan suppress regeneration by inhibiting support cell division. This observation is in agreement with other studies suggesting that hair cell regeneration in the zebrafish lateral line is accomplished solely through mitotic replacement of lost hair cells (Harris et al., 2003; López-Schier and Hudspeth, 2006; Ma et al., 2008; Wibowo et al., 2011). This is in sharp contrast to regeneration in the inner ear of birds and amphibians, where substantial transdifferentiation normally occurs and is accentuated by blocking the mitotic response (Adler and Raphael, 1996; Baird et al., 1996; Roberson et al., 1996; Baird et al., 2000; Roberson et al., 2004; Taylor and Forge, 2005).

We observe 1-3 GFP +/BrdU - hair cells within neuromasts of fish treated with flubendazole after neomycin treatment. These hair cells are likely to have been immature hair cells not susceptible to neomycin-induced death at the time of treatment (Santos et al., 2006). Nevertheless, we currently lack markers to distinguish between support cells and immature post-mitotic hair cells, thus we cannot rule out the possibility that some direct transdifferentiation occurs in zebrafish after neomycin treatment.

The more moderate inhibitor of regeneration, fulvestrant, is an estrogen receptor (ER) antagonist. Fulvestrant is thought to act by downregulating and degrading estrogen and progesterone receptors (Wakeling et al., 1991; Howell et al., 2000; Osborne et al., 2004). Support cell divisions in the neuromast are reduced in the presence of fulvestrant, suggesting that the drug may be affecting the signaling pathways involved in cellular proliferation. It is unknown whether fulvestrant acts on ER signaling in hair cells and if so, which ERs are affected. Estrogen signaling has been implicated in proliferative signaling during avian hair cell regeneration (McCullar and Oesterle, 2009) and a microarray study detected significant upregulation of estrogen receptors after either aminoglycoside antibiotic or laser damage of chicken auditory and vestibular epithelia (Hawkins et al., 2007). The esr2a and esr $2 b$ estrogen receptor transcripts are abundant in both hair cells and support cells within zebrafish lateral line neuromasts during development (Tingaud-Sequeira et al., 2004); blocking esr2a expression prevents hair cell development without affecting sup- port cells (Froehlicher et al., 2009). Hence, fulvestrant may be suppressing hair cell regeneration by interfering with ER signaling.

The predominant cause of hearing loss in humans is the death of the mechanosensory hair cells of the inner ear. In 1987, it was discovered that birds regenerate damaged and lost inner ear hair cells (Cotanche, 1987; Cruz et al., 1987). Since that time, considerable progress has been made (Collado et al., 2008; Löwenheim et al., 2008; Brigande and Heller, 2009; Groves, 2010), but robust regeneration is yet to be achieved in the inner ear of mature mammals. Our results demonstrate that the zebrafish lateral line system provides a platform for high throughput screening to identify new modulators of hair cell regeneration. Extension of the methods described here to new compound libraries may provide additional tools to dissect regeneration in systems that can normally undergo this process and perhaps promote regeneration in those that do not.

\section{References}

Adler HJ, Raphael Y (1996) New hair cells arise from supporting cell conversion in the acoustically damaged chick inner ear. Neurosci Lett 205:17-20.

Baird RA, Steyger PS, Schuff NR (1996) Mitotic and nonmitotic hair cell regeneration in the bullfrog vestibular otolith organs. Ann N Y Acad Sci 781:59-70.

Baird RA, Burton MD, Lysakowski A, Fashena DS, Naeger RA (2000) Hair cell recovery in mitotically blocked cultures of the bullfrog saccule. Proc Natl Acad Sci U S A 97:11722-11729.

Bhave SA, Oesterle EC, Coltrera MD (1998) Macrophage and microglia-like cells in the avian inner ear. J Comp Neurol 398:241-256.

Breuskin I, Bodson M, Thelen N, Thiry M, Nguyen L, Belachew S, Lefebvre PP, Malgrange B (2008) Strategies to regenerate hair cells: identification of progenitors and critical genes. Hear Res 236:1-10.

Brigande JV, Heller S (2009) Quo vadis, hair cell regeneration? Nat Neurosci 12:679-685.

Brignull HR, Raible DW, Stone JS (2009) Feathers and fins: nonmammalian models for hair cell regeneration. Brain Res 1277:12-23.

Cafaro J, Lee GS, Stone JS (2007) Atoh1 expression defines activated progenitors and differentiating hair cells during avian hair cell regeneration. Dev Dyn 236:156-170.

Chen P, Segil N (1999) p27(Kip1) links cell proliferation to morphogenesis in the developing organ of Corti. Development 126:1581-1590.

Coffin AB, Reinhart KE, Owens KN, Raible DW, Rubel EW (2009) Extracellular divalent cations modulate aminoglycoside-induced hair cell death in the zebrafish lateral line. Hear Res 253:42-51.

Coffin AB, Ou H, Owens KN, Santos F, Simon JA, Rubel EW, Raible DW (2010) Chemical screening for hair cell loss and protection in the zebrafish lateral line. Zebrafish 7:3-11.

Collado MS, Burns JC, Hu Z, Corwin JT (2008) Recent advances in hair cell regeneration research. Curr Opin Otolaryngol Head Neck Surg 16:465-471.

Corwin JT, Cotanche DA (1988) Regeneration of sensory hair cells after acoustic trauma. Science 240:1772-1774.

Cotanche DA (1987) Regeneration of hair cell stereociliary bundles in the chick cochlea following severe acoustic trauma. Hear Res 30:181-195.

Cruz RM, Lambert PR, Rubel EW (1987) Light microscopic evidence of hair cell regeneration after gentamicin toxicity in chick cochlea. Arch Otolaryngol Head Neck Surg 113:1058-1062.

Cumino AC, Elissondo MC, Denegri GM (2009) Flubendazole interferes with a wide spectrum of cell homeostatic mechanisms in Echinococcus granulosus protoscoleces. Parasitol Int 58:270-277.

Daudet N, Gibson R, Shang J, Bernard A, Lewis J, Stone J (2009) Notch regulation of progenitor cell behavior in quiescent and regenerating auditory epithelium of mature birds. Dev Biol 326:86-100.

Edge AS, Chen ZY (2008) Hair cell regeneration. Curr Opin Neurobiol 18:377-382.

Fleming A, Sato M, Goldsmith P (2005) High-throughput in vivo screening for bone anabolic compounds with zebrafish. J Biomol Screen 10:823-831.

Froehlicher M, Liedtke A, Groh K, López-Schier H, Neuhauss SC, Segner H, 
Eggen RI (2009) Estrogen receptor subtype beta2 is involved in neuromast development in zebrafish (Danio rerio) larvae. Dev Biol 330:32-43.

Geling A, Steiner H, Willem M, Bally-Cuif L, Haass C (2002) A gammasecretase inhibitor blocks Notch signaling in vivo and causes a severe neurogenic phenotype in zebrafish. EMBO Rep 3:688-694.

Groves AK (2010) The challenge of hair cell regeneration. Exp Biol Med (Maywood) 235:434-446.

Harris JA, Cheng AG, Cunningham LL, MacDonald G, Raible DW, Rubel EW (2003) Neomycin-induced hair cell death and rapid regeneration in the lateral line of zebrafish (Danio rerio). J Assoc Res Otolaryngol 4:219-234.

Hawkins RD, Bashiardes S, Powder KE, Sajan SA, Bhonagiri V, Alvarado DM, Speck J, Warchol ME, Lovett M (2007) Large scale gene expression profiles of regenerating inner ear sensory epithelia. PLoS One 2:e525.

Hernández PP, Moreno V, Olivari FA, Allende ML (2006) Sub-lethal concentrations of waterborne copper are toxic to lateral line neuromasts in zebrafish (Danio rerio). Hear Res 213:1-10.

Hernández PP, Olivari FA, Sarrazin AF, Sandoval PC, Allende ML (2007) Regeneration in zebrafish lateral line neuromasts: expression of the neural progenitor cell marker sox 2 and proliferation-dependent andindependent mechanisms of hair cell renewal. Dev Neurobiol 67: 637-654.

Howell A, Osborne CK, Morris C, Wakeling AE (2000) ICI 182,780 (Faslodex): development of a novel, "pure" antiestrogen. Cancer 89:817-825.

Hübner G, Brauchle M, Smola H, Madlener M, Fässler R, Werner S (1996) Differential regulation of pro-inflammatory cytokines during wound healing in normal and glucocorticoid-treated mice. Cytokine 8:548-556.

Isobe T, Lillehoj HS (1992) Effects of corticosteroids on lymphocyte subpopulations and lymphokine secretion in chickens. Avian Dis 36:590-596.

Izumikawa M, Minoda R, Kawamoto K, Abrashkin KA, Swiderski DL, Dolan DF, Brough DE, Raphael Y (2005) Auditory hair cell replacement and hearing improvement by Atohl gene therapy in deaf mammals. Nat Med 11:271-276.

Jones JE, Corwin JT (1996) Regeneration of sensory cells after laser ablation in the lateral line system: hair cell lineage and macrophage behavior revealed by time-lapse video microscopy. J Neurosci 16:649-662.

Jørgensen JM, Mathiesen C (1988) The avian inner ear. Continuous production of hair cells in vestibular sensory organs, but not in the auditory papilla. Naturwissenschaften 75:319-320.

Kollmannsberger C, Mross K, Jakob A, Kanz L, Bokemeyer C (1999) Topotecan-A novel topoisomerase I inhibitor: pharmacology and clinical experience. Oncology 56:1-12.

Koster DA, Palle K, Bot ES, Bjornsti MA, Dekker NH (2007) Antitumour drugs impede DNA uncoiling by topoisomerase I. Nature 448:213-217.

Lanford PJ, Lan Y, Jiang R, Lindsell C, Weinmaster G, Gridley T, Kelley MW (1999) Notch signalling pathway mediates hair cell development in mammalian cochlea. Nat Genet 21:289-292.

Li H, Liu H, Heller S (2003) Pluripotent stem cells from the adult mouse inner ear. Nat Med 9:1293-1299.

López-Schier H, Hudspeth AJ (2006) A two-step mechanism underlies the planar polarization of regenerating sensory hair cells. Proc Natl Acad Sci U S A 103:18615-18620.

Lorusso D, Pietragalla A, Mainenti S, Masciullo V, Di Vagno G, Scambia G (2010) Review role of topotecan in gynaecological cancers: current indications and perspectives. Crit Rev Oncol Hematol 74:163-174.

Löwenheim H, Furness DN, Kil J, Zinn C, Gültig K, Fero ML, Frost D, Gummer AW, Roberts JM, Rubel EW, Hackney CM, Zenner HP (1999) Gene disruption of p27(Kip1) allows cell proliferation in the postnatal and adult organ of corti. Proc Natl Acad Sci U S A 96:4084-4088.

Löwenheim H, Waldhaus J, Hirt B, Sandke S, Müller M (2008) [Regenerative medicine in the treatment of sensorineural hearing loss]. HNO $56: 288-300$

Ma EY, Rubel EW, Raible DW (2008) Notch signaling regulates the extent of hair cell regeneration in the zebrafish lateral line. J Neurosci 28:2261-2273.

Mathew LK, Sengupta S, Kawakami A, Andreasen EA, Löhr CV, Loynes CA, Renshaw SA, Peterson RT, Tanguay RL (2007) Unraveling tissue regeneration pathways using chemical genetics. J Biol Chem 282:35202-35210.

McCullar JS, Oesterle EC (2009) Cellular targets of estrogen signaling in regeneration of inner ear sensory epithelia. Hear Res 252:61-70.

Montcouquiol M, Corwin JT (2001) Intracellular signals that control cell proliferation in mammalian balance epithelia: key roles for phosphatidylinositol-3 kinase, mammalian target of rapamycin, and S6 kinases in preference to calcium, protein kinase $C$, and mitogenactivated protein kinase. J Neurosci 21:570-580.

Murakami SL, Cunningham LL, Werner LA, Bauer E, Pujol R, Raible DW, Rubel EW (2003) Developmental differences in susceptibility to neomycin-induced hair cell death in the lateral line neuromasts of zebrafish (Danio rerio). Hear Res 186:47-56.

Nicolson T (2005) The genetics of hearing and balance in zebrafish. Annu Rev Genet 39:9-22.

Oesterle EC, Cunningham DE, Westrum LE, Rubel EW (2003) Ultrastructural analysis of $[3 \mathrm{H}]$ thymidine-labeled cells in the rat utricular macula. J Comp Neurol 463:177-195.

Oesterle EC and Stone JS (2008) Hair cell regeneration: mechanisms guiding cell proliferation and differentiation. In: Hair cell regeneration, repair, and protection, Vol 33 (Salvi R, Fay R, Popper A, eds), pp 141-197. New York: Springer.

O'Halloran EK, Oesterle EC (2004) Characterization of leukocyte subtypes in chicken inner ear sensory epithelia. J Comp Neurol 475:340-360.

Oppedal D, Goldsmith MI (2010) A chemical screen to identify novel inhibitors of fin regeneration in zebrafish. Zebrafish 7:53-60.

Osborne CK, Wakeling A, Nicholson RI (2004) Fulvestrant: an oestrogen receptor antagonist with a novel mechanism of action. Br J Cancer 90:S2-S6.

Ou HC, Cunningham LL, Francis SP, Brandon CS, Simon JA, Raible DW, Rubel EW (2009) Identification of FDA-approved drugs and bioactives that protect hair cells in the zebrafish (Danio rerio) lateral line and mouse (Mus musculus) utricle. J Assoc Res Otolaryngol 10:191-203.

Ou HC, Santos F, Raible DW, Simon JA, Rubel EW (2010) Drug screening for hearing loss: using the zebrafish lateral line to screen for drugs that prevent and cause hearing loss. Drug Discov Today 15:265-271.

Owens KN, Santos F, Roberts B, Linbo T, Coffin AB, Knisely AJ, Simon JA, Rubel EW, Raible DW (2008) Identification of genetic and chemical modulators of zebrafish mechanosensory hair cell death. PLoS Genet 4:e1000020.

Owens KN, Coffin AB, Hong LS, Bennett KO, Rubel EW, Raible DW (2009) Response of mechanosensory hair cells of the zebrafish lateral line to aminoglycosides reveals distinct cell death pathways. Hear Res 253:32-41.

Raible DW, Kruse GJ (2000) Organization of the lateral line system in embryonic zebrafish. J Comp Neurol 421:189-198.

Rhen T, Cidlowski JA (2005) Antiinflammatory Action of GlucocorticoidsNew Mechanisms for Old Drugs. N Engl J Med 353:1711-1723.

Roberson DW, Rubel EW (1994) Cell division in the gerbil cochlea after acoustic trauma. Am J Otol 15:28-34.

Roberson DW, Kreig CS, Rubel EW (1996) Light microscopic evidence that direct transdifferentiation gives rise to new hair cells in regenerating avian auditory epithelium. Auditory Neuroscience 2:195-205.

Roberson DW, Alosi JA, Cotanche DA (2004) Direct transdifferentiation gives rise to the earliest new hair cells in regenerating avian auditory epithelium. J Neurosci Res 78:461-471.

Ryals BM, Rubel EW (1988) Hair cell regeneration after acoustic trauma in adult Coturnix quail. Science 240:1774-1776.

Sage C, Huang M, Karimi K, Gutierrez G, Vollrath MA, Zhang DS, GarcíaAñoveros J, Hinds PW, Corwin JT, Corey DP, Chen ZY (2005) Proliferation of functional hair cells in vivo in the absence of the retinoblastoma protein. Science 307:1114-1118.

Sage C, Huang M, Vollrath MA, Brown MC, Hinds PW, Corey DP, Vetter DE, Chen ZY (2006) Essential role of retinoblastoma protein in mammalian hair cell development and hearing. Proc Natl Acad Sci USA 103:7345-7350.

Santos F, MacDonald G, Rubel EW, Raible DW (2006) Lateral line hair cell maturation is a determinant of aminoglycoside susceptibility in zebrafish (Danio rerio). Hear Res 213:25-33.

Schaaf MJ, Chatzopoulou A, Spaink HP (2009) The zebrafish as a model system for glucocorticoid receptor research. Comp Biochem Physiol A Mol Integr Physiol 153:75-82.

Spagnuolo PA, Hu J, Hurren R, Wang X, Gronda M, Sukhai MA, Di Meo A, Boss J, Ashali I, Beheshti Zavareh R, Fine N, Simpson CD, Sharmeen S, Rottapel R, Schimmer AD (2010) The antihelmintic flubendazole inhibits microtubule function through a mechanism distinct from Vinca alkaloids and displays preclinical activity in leukemia and myeloma. Blood 115:4824-4833. 
Staker BL, Hjerrild K, Feese MD, Behnke CA, Burgin AB Jr, Stewart L (2002) The mechanism of topoisomerase I poisoning by a camptothecin analog. Proc Natl Acad Sci U S A 99:15387-15392.

Stone JS, Cotanche DA (2007) Hair cell regeneration in the avian auditory epithelium. Int J Dev Biol 51:633-647.

Stone JS, Rubel EW (1999) Deltal expression during avian hair cell regeneration. Development 126:961-973.

Taylor RR, Forge A (2005) Hair cell regeneration in sensory epithelia from the inner ear of a urodele amphibian. J Comp Neurol 484:105-120.

Tingaud-Sequeira A, André M, Forgue J, Barthe C, Babin PJ (2004) Expression patterns of three estrogen receptor genes during zebrafish (Danio rerio) development: evidence for high expression in neuromasts. Gene Expr Patterns 4:561-568.

Ton C, Parng C (2005) The use of zebrafish for assessing ototoxic and otoprotective agents. Hear Res 208:79-88.

Wakeling AE, Dukes M, Bowler J (1991) A potent specific pure antiestrogen with clinical potential. Cancer Res 51:3867-3873.

Warchol ME (1997) Macrophage activity in organ cultures of the avian cochlea: demonstration of a resident population and recruitment to sites of hair cell lesions. J Neurobiol 33:724-734.

Warchol ME (1999) Immune cytokines and dexamethasone influence sen- sory regeneration in the avian vestibular periphery. J Neurocytol 28:889-900.

Warchol ME (2011) Sensory regeneration in the vertebrate inner ear: differences at the levels of cells and species. Hear Res 273:72-79.

Warchol ME, Matsui JI, Simkus EL, Ogilive JM (2001) Ongoing cell death and immune influences on regeneration in the vestibular sensory organs. Ann N Y Acad Sci 942:34-45.

Westerfield M (1995) The zebrafish book. A guide for the laboratory use of zebrafish (Danio rerio), Ed 3. Eugene: University of Oregon Press.

Whitfield TT (2002) Zebrafish as a model for hearing and deafness. J Neurobiol 53:157-171.

Wibowo I, Pinto-Teixeira F, Satou C, Higashijima S, López-Schier H (2011) Compartmentalized Notch signaling sustains epithelial mirror symmetry. Development 138:1143-1152.

Williams JA, Holder N (2000) Cell turnover in neuromasts of zebrafish larvae. Hear Res 143:171-181.

Xiao T, Roeser T, Staub W, Baier H (2005) A GFP-based genetic screen reveals mutations that disrupt the architecture of the zebrafish retinotectal projection. Development 132:2955-2967.

Zheng JL, Gao WQ (2000) Overexpression of Math1 induces robust production of extra hair cells in postnatal rat inner ears. Nat Neurosci 3:580586. 